\title{
Review Article \\ Importance of Silicon and Mechanisms of Biosilica Formation in Plants
}

\author{
Mahbod Sahebi, ${ }^{1}$ Mohamed M. Hanafi, ${ }^{1,2}$ Abdullah Siti Nor Akmar, ${ }^{1}$ Mohd Y. Rafii, ${ }^{3}$ \\ Parisa Azizi, ${ }^{3}$ F. F. Tengoua, ${ }^{1}$ Jamaludin Nurul Mayzaitul Azwa, ${ }^{1}$ and M. Shabanimofrad ${ }^{3}$ \\ ${ }^{1}$ Laboratory of Plantation Crops, Institute of Tropical Agriculture, Universiti Putra Malaysia, 43400 Serdang, Selangor, Malaysia \\ ${ }^{2}$ Department of Land Management, Faculty of Agriculture, 43400 Serdang, Selangor, Malaysia \\ ${ }^{3}$ Laboratory of Food Crops, Institute of Tropical Agriculture, Universiti Putra Malaysia, 43400 Serdang, Selangor, Malaysia
}

Correspondence should be addressed to Mohamed M. Hanafi; mmhanafi@agri.upm.edu.my

Received 3 July 2014; Revised 18 December 2014; Accepted 23 December 2014

Academic Editor: Kexuan Tang

Copyright (C) 2015 Mahbod Sahebi et al. This is an open access article distributed under the Creative Commons Attribution License, which permits unrestricted use, distribution, and reproduction in any medium, provided the original work is properly cited.

\begin{abstract}
Silicon $(\mathrm{Si})$ is one of the most prevalent macroelements, performing an essential function in healing plants in response to environmental stresses. The purpose of using $\mathrm{Si}$ is to induce resistance to distinct stresses, diseases, and pathogens. Additionally, $\mathrm{Si}$ can improve the condition of soils, which contain toxic levels of heavy metals along with other chemical elements. Silicon minimizes toxicity of $\mathrm{Fe}, \mathrm{Al}$, and $\mathrm{Mn}$, increases the availability of $\mathrm{P}$, and enhances drought along with salt tolerance in plants through the formation of silicified tissues in plants. However, the concentration of Si depends on the plants genotype and organisms. Hence, the physiological mechanisms and metabolic activities of plants may be affected by $\mathrm{Si}$ application. Peptides as well as amino acids can effectively create polysilicic species through interactions with different species of silicate inside solution. The carboxylic acid and the alcohol groups of serine and asparagine tend not to engage in any significant role in polysilicates formation, but the hydroxyl group side chain can be involved in the formation of hydrogen bond with $\mathrm{Si}(\mathrm{OH})_{4}$. The mechanisms and trend of Si absorption are different between plant species. Furthermore, the transportation of Si requires an energy mechanism; thus, low temperatures and metabolic repressors inhibit Si transportation.
\end{abstract}

\section{Introduction}

Generally, food security and health concerns are two critical issues, for human life. Due to the population growth, especially in developing countries, and the spread of communicable and noncommunicable diseases in human population, having a flexible agricultural system is more necessary than ever. Agricultural systems are reliable ways to increase food for the humans by using natural resources. To increase the food qualities and quantities, plants should utilize different strategies to overcome the adverse environmental effects. By utilizing genes strategies, plants can increase their resistance against negative environmental impacts. Along with that, scientists made an effort to increase plants tolerance against pathogens. Silicon $(\mathrm{Si})$, as a macroelement, has a vital role in plants cycles. This element is the eighth most common element in nature and the second most common element found in soil after oxygen. One of the main functions of $\mathrm{Si}$ is improving the plants growth and yield especially in stress condition. To achieve plant tolerance, Si promotes plant photosynthesis by favourably exposing leaves to light. On the other hand, the role of the macroelement has proven to be in response to different abiotic and biotic stress. Meaningfully, increasing resistance to diseases and pathogens, metal toxicities, salinity and drought stresses are some of the most important functions of this factor. Indeed, protecting plants against extremely high or low temperature needed for nodule configuration, as well as for beneficial effect over the mineral composition and enzyme activities of plants are other advantages of the macroelement [1]. Plant growth depends on several elements existing in the soil. These elements can be categorised into beneficial, essential, and toxic groups [2]. Toxic elements unconstructively affect plant growth, while essential elements display critical roles for all plants in different growth conditions. Beneficial elements are vital for some specific plant species growing under certain growth situations. 
The beneficial effects of Si on different plant species are well documented. Notwithstanding the above advantages of this factor, some scientists still believe in unnecessary function of $\mathrm{Si}$ in plants cycles. In contrast, lack of documented proof conducted researchers to find the proper role of this element in plants. The second group believes $\mathrm{Si}$ is an omnipresent and important element of plants and soil. In addition, they observed that Si has many beneficial roles in crop performance and life [3]. For example, results of a study on the function of Si over controlling powdery mildew in cucumber demonstrated this macroelement is able to produce inactive phytoalexins or glycosylated [4], which are activated by infection of Si-treated plants with fungi leading to cell death of fungi [5]. It has been reported that $\mathrm{Si}$ is able to increase stress tolerance and decrease membrane damage in tomato (Solanumly copersicum) and spinach (Spinacia oleracea) [6]. On the other hand, Si helps wheat (Triticum spp.) to overcome oxidative damage in pots under drought stress and powdery mildew $[7,8]$. Silicon also leads sorghum (Sorghum bicolor) to enhance drought tolerance [9], rice (Oryza sativa) to enhance sheath blight (Rhizoctonia solani) and blast disease resistance [10-12], sugarcane (Saccharum officinarum) to decrease susceptibility against eldana saccharina (Lepidoptera: Pyralidae) [13], barley (Hordeum vulgare L.) $[14,15]$ and cucumber (Cucumis sativus) to increase salt tolerance [14-16], and maize (Zea mays subsp. mays) to enhance cadmium tolerance, decline aluminium toxicity, and improve efficiency of using water [17-19]. Moreover, the main important role of Si in plants is during exposing to abiotic and biotic stress. The macroelement is able to suppress these stresses in plants, leading to higher plant productivity [20]. To support, fertilisation of paddy soil with Si, which began in 1955 in Japan, increased rice production tremendously [21].

Additionally, according to results of an investigation released, plants treated with Si have strong structure [22]. Moreover, these plants in comparison to control are more resistant against biotic and abiotic stress such as pathogens and metal toxicities, respectively. The results of investigation also strongly confirmed the biosilica formation role of the serine-rich protein gene in transgenic Arabidopsis thaliana [23].

Generally, the above proof released the necessary function of Si in pant cycles [22]. Most of soils are able to provide sufficient nutrients for plants without any extra fertiliser. However, increasing of plant growth and productivity can be affected by artificially modifying the soil nutrients through fertilisation because plants can obtain necessary nutrients from the fertilised soil. Adding Si as fertilizer to the soil may not provide the same efficiency for all plants and crops in different geographical areas and soil conditions. Hence, genetic modification of plants in order to absorb more Si from the soil and accumulate it in their roots and shoots seems to give more efficient and sustainable results. Cation exchange resulting from hydrogen $\left(\mathrm{H}^{+}\right)$pumping by the root hairs of plants leads to nutrient uptake because the $\mathrm{H}^{+}$ions relocate the cations (negatively charged particles) that are attached to the soil particles into the plant roots. In this review, we illustrate several physiological, biochemical, and molecular factors that affect $\mathrm{Si}$ absorption and biosilica formation mechanisms in plants. Additionally, this review provides useful information regarding a previously discovered novel serine-rich protein gene that plays a crucial role in the biosilica formation in plants [24].

\section{Important Roles of Silicon}

2.1. Forms of Si in Soil. Each kilogram of soil usually contains $\mathrm{Si}$ ranging from 50 to 400 grams. Silicon dioxide $\left(\mathrm{SiO}_{2}\right)$ is the common form of $\mathrm{Si}$ in soil. Vermiculite, smectite, kaolin (rich minerals in soils), orthoclase, feldspars, plagioclase (silicates in the form of crystal), amorphous silica, and quartz are the main Si components in most soils structures [25]. Solubility of all the above Si forms is low and biogeochemically immobile. The major soluble forms of $\mathrm{Si}$ in the soil are poly- and monosilicic acids [26]; however, monosilicic acid occurs mostly in a feebly adsorbed condition [27] and has low capability to migrate inside the soil [28]. By increasing the monosilicic acid concentration in the soil solution, plants are able to absorb phosphates $(\mathrm{P})$ directly. The amount of monosilicic acid is increased because of chemical resemblance between phosphate and silicate anions causing a competitive reaction in the soil [29]. Insolubility of monosilicic acid decreases slightly through interactions with heavy metals, iron, aluminium, and manganese [30].

Essential soil components are polysilicic acids that commonly influence the physical properties of soils. In contrast, monosilicic acidic adsorbent is chemically immobile and makes colloidal particles [31]. Thus, polysilicic acids interfere with soil structure formation and soil water-holding [32]. In the biochemical processes which occur in the soil, the Si function is highlighted because this element possesses chemical properties that can create molecules with useful biological functions. The main drawback of $\mathrm{Si}$ is the disability of this element to form chemical bonds with different types of atoms that are necessary for the chemical versatility of metabolism. This disability is caused by the size and the molecular mass of the Si atom, which leads to limiting interaction with the other atoms and the formation of monotonous molecules.

\subsection{Silicon and Plants}

2.2.1. Variability of Si Contents in Various Plant Species. Among plants, sugarcane (Saccharum officinarum), rice (Oryza sativa), and wheat (Triticum spp.) absorb the largest amount of Si, with 300-700, 150-300, and 50-150 kg Si ha ${ }^{-1}$, respectively [33]. Generally, Si uptake in graminaceous plants is much higher than its uptake in other plant species. For example, rice is a common $\mathrm{Si}$-collector that absorbs $\mathrm{Si}$ in active progression [34], as other graminaceous plants do including wheat (Triticum spp.) [35], barley (Hordeum vulgare L.) [36], ryegrass (Lolium perenne) [37], maize (Zea mays subsp. Mays) [38], and some cyperaceous plants. The majority of dicotyledon plants, such as cucumbers (Cucumis sativus), melons, strawberries, and soybeans (Glycine max L. Merr) absorb Si inertly [39]. Nonetheless, some plants especially dicotyledon, such as tomatoes (Solanum lycopersicum), beans, and other plants, are not able to absorb Si from soil [39-42]. 


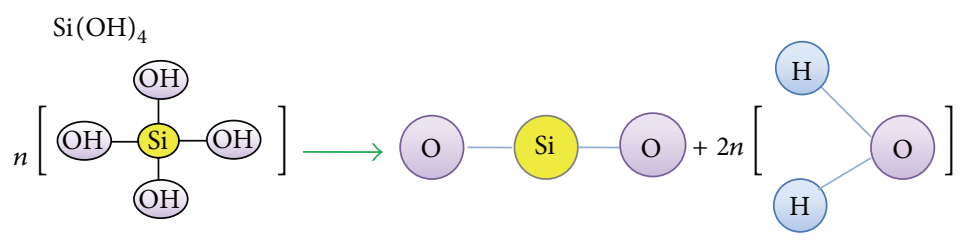

FIgURE 1: Mono- and polysilicic acids hydration.
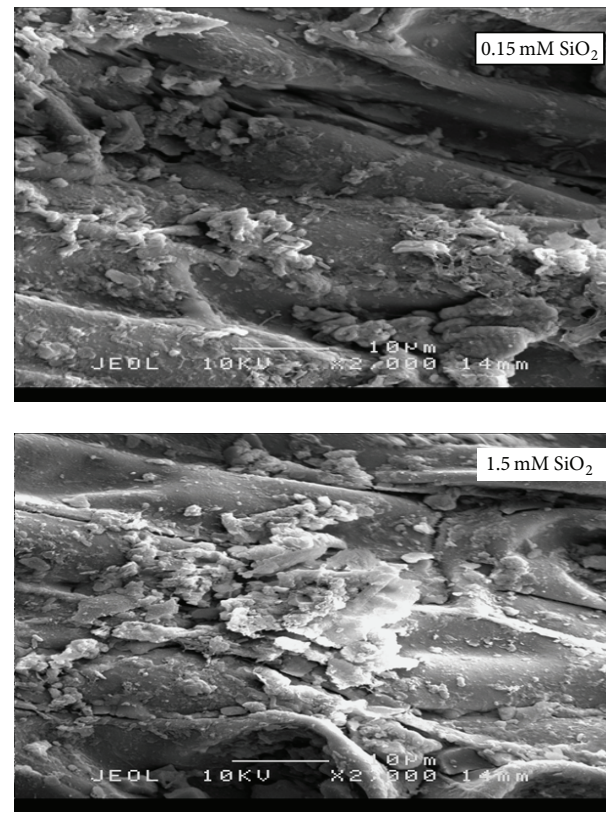

FIGURE 2: Scanning electron microscopy image of Si absorption by roots of mangrove under different concentrations of $\mathrm{SiO}_{2}$ in Hoagland's solution.

2.2.2. Absorption Forms of Si by Plants. Monosilicic acid or orthosilicic acid $\left(\mathrm{H}_{4} \mathrm{SiO}_{4}\right)$ is the $\mathrm{Si}$ forms that are absorbed by plants root $[43,44]$. Consequently, $\mathrm{Si}$ accumulates in the epidermal tissues, and a layer of cellulose membrane-Si is created when $\mathrm{Ca}$ and pectin ions are present [45], which provides protection to the plant $[19,46,47]$. Increasing of $\mathrm{Si}$ in the sap of plants leads to Si polymerisation [48], identified as Si gel hydrated with water molecules [49]. The process of mono- and polysilicic acids hydration is as follows (Figure 1).

Recently, Nurul Mayzaitul Azwa (personal commun.) reported that mangrove plants can absorb large amounts of $\mathrm{Si}$ from the soil solution (Figure 2). Amorphous silica is the final form of $90 \%$ of absorbed and transformed $\mathrm{Si}$ in $\mathrm{Si}$ cellulose structures [50]. A nanometre level of biogenic silica is produced as intercell structures [51]. Concentration of $\mathrm{Si}$ differs significantly in the shoots and roots of plants, and this extensive variation in different plant tissues is related to differences in the mechanisms of Si uptake and transportation $[52,53]$. Nutrient uptake by plants depends on the potential of water and the solubility of elements in the soils. The nutrients uptake pathway is from the soil solution with a higher solute concentration to plant tissues with a lower solute concentration. Although Si is found plentifully in both silicate and oxidase forms in the soil, Si solubility in the soil solution is an obstacle for plant absorption because monosilicic acid is the only form of Si that plants can absorb.

2.3. Silicon and Abiotic Stresses. It has been widely reported that $\mathrm{Si}$ is able to suppress both physical stress, such as drought, high temperature, UV, loading, and freezing, and chemical stress, including salinity, nutrient imbalance, and metal toxicity $[54,55]$.

2.3.1. Silicon and Salinity Stress. Salinity stress, a major yield restraining factor in dry and semidry areas, can be repressed by increasing Si [56]. Silicon indirectly reduces the oxidative damage of cucumber tissues under salt stress through the activities of guaiacol peroxidase, ascorbate peroxidase, superoxide dismutase, dehydroascorbate reductase, and glutathione reductase [16]. Oxidative damage in tomato leaves decreases with increasing $\mathrm{Si}$ [5], resulting in increased activity of catalase and superoxide dismutase enzymes, increased protein content in the tomato leaves, decreased ascorbate peroxidase enzyme, decreased malondialdehyde concentration, and decreased $\mathrm{H}_{2} \mathrm{O}_{2}$ levels [57]. The alleviative effect of $\mathrm{Si}$ over salinity stress has been demonstrated in wheat (Triticum spp.) [55, 58], rice (Oryza sativa) [55, 59], barley (Hordeum vulgare L.) $[14,40,55,60]$, mesquite [61], tomato (Solanum lycopersicum) [57, 62], cucumber (Cucumis sativus) [63], and maize (Zea mays subsp. mays) $[64,65]$. The roots and shoots of Si-treated rice plants under salinity stress notably improved when compared to control plants [66]. It has been reported that the salt tolerance of mesquite and wheat can be increased significantly after supplying a Si nutrient solution at small amounts [58]. Along with that, the salinity tolerance of hydroponically cultured rice can be increased by adding Si to the nutrient solution [67]. Adding Si decreased the concentration of $\mathrm{Na}$ in barley shoots [68] and rice shoots [69].

The positive physiologic effects of silicon on improvement of plants are in conjunction with the endogenous stress responses of plants in different environmental condition [70]. Silicon is able to increase soluble protein content of plants' leaves, which helps plants to overcome salt stress by replacing the lost soluble protein content under salinity stress [16]. Silicon can also increase the antioxidant enzyme activity of superoxide dismutase (SOD), guaiacol peroxidase (GPX), ascorbate peroxidase (APX), dehydroascorbate reductase (DHAR), and glutathione reductase (GR) in plants under salt-stress $[14,16,68]$. The induced oxidative damage by salt can be decreased through decreasing in level of electrolyte leakage percentage (ELP), lipid peroxidation (LPO), and $\mathrm{H}_{2} \mathrm{O}_{2}$ content [16]. This enzymatic protection mechanism 
helps plants to overcome salinity stress damage [71-73]. A considerable enhancement in the antioxidant enzyme activities in leaves of salt-stressed cucumber by additional Si treatment suggested that $\mathrm{Si}$ can be involved in physiological or metabolic cycles of plants [16]. The Si nutrition increased catalase activity significantly in all parts of plants and peroxidase activity in cell wall of plant's shoots $[57,74]$.

From the physical stand point, $\mathrm{Si}$ is able to decrease the plasma membrane permeability in leaf cells of plants which resulted in reducing the lipid peroxidation levels. The Si application of plants under stress condition leads to decreasing lignin content in cell walls of plant's shoots. It was reported that application of $\mathrm{Si}$ in canola plants resulted in decreasing Si content in shoot parts of plants by formatting complexes of Si-polyphenol or substitution of Si and lignin [75]. These physical changes in plants' cell wall could facilitate loosening process and promote cell extension, which results in plants' growth under salt stress $[74,76]$. The Si protects plants from environmental stress, such as drought and heat, by providing more stable lipids involved in their cell membrane [16, 77].

It was considered that Si-induced motivation from plasma membrane of roots might increase absorption and transportation of $\mathrm{K}$ and decrease the uptake and transportation of $\mathrm{Na}$ from the roots to shoots of barley under salinity [60]. On the other hand, $\mathrm{Na}^{+}$ion concentration in canola tissues under salt stress is decreased with Si application. The $\mathrm{Si}$ accumulation in the endodermis and cell walls of plants could reduce the $\mathrm{Na}$ accumulation in roots and shoots via a diminution in apoplastic transportation [74, 78-81]. Plants under salinity stress encounter low water potential from the outside because of the high $\mathrm{Na}^{+}$and $\mathrm{Cl}^{-}$content in the soil and salt deposition in the other plant cellular regions [82]. These ions move to the aerial parts of plants via transpiration, and when $\mathrm{Na}^{+}$and $\mathrm{Cl}^{-}$are at a toxic threshold, different plant tissues can be harshly damaged. The hydrophilic nature of $\mathrm{Si}$ can decrease the poisonous levels of saline ions and reduce the osmotic effect of salt stress on the absorption and storage of water by plants. Additionally, Si treatment in plants results in enlarged leaf cells via cell wall expansion, which helps the plants to hold more water. Reportedly, Si treated plants grown under saline stress have a larger leaf weight ratio and a smaller specific leaf area than untreated plants, which have smaller leaf surface areas and loss of water transpiration [58]. It has been shown that when salinised plants were treated with $\mathrm{Si}$, their water amounts increased up to $40 \%$. Moreover, the turgor potential of plants treated with both $\mathrm{NaCl}$ and $\mathrm{Si}$ was $42 \%$ higher than that of $\mathrm{NaCl}$-treated plants [62]. Silicontreated salinised plants showed $17 \%$ higher efficiency in using water than untreated plants [16]. This suggests that $\mathrm{Si}$ is able to alleviate the harmful effects of salinity stress. Silicon can decrease lipid peroxidation in plants exposed to salinity stress by enhancing the enzymatic and nonenzymatic activities of antioxidants $[16,57]$. Silicon application to the plants under salt stress limits the transpiration ratio and increases root activities. Decreases in transpiration lead to reduced osmotic stresses in plant cells and improved root activities. As consequence of root activities, plants can increase the nutrients uptake and decrease salt toxicity. Silicon absorption by plants leads to increased PPase and ATPase activities in vacuoles, which reduces $\mathrm{Na}^{+}$uptake and enhances $\mathrm{K}^{+}$uptake by the cell membrane. Separation of salt ions into the vacuoles and increasing the $\mathrm{K}^{+} / \mathrm{Na}^{+}$ratio in the cells of the roots and leaves decrease $\mathrm{Na}^{+}$toxicity. Increasing antioxidative enzymatic activities cease electron losses from the lipids in cell membranes, which decreases lipid peroxidation and cell damage. The schematic of the mechanism of the interaction of $\mathrm{Si}$ treatment in plants under salinity stress is shown in Figure 3.

\subsubsection{Silicon and Heavy Metals}

(1) Silicon and Manganese Toxicity. The role of Si in suppression of heavy metal toxicity is broadly noted in higher plants. The alleviating role of Si against $\mathrm{Mn}$ in the solution culture of barley was first discovered in 1957 [83, 84]. Although Si is not able to affect the whole $\mathrm{Mn}$ in barley leaves, it is able to evenly distribute $\mathrm{Mn}$ across the entire leaf and does not allow Mn to concentrate in distinct necrotic spots [85]. Additionally, the function of $\mathrm{Si}$ in alleviating $\mathrm{Mn}$ toxicity has been widely reported in rice [55], pumpkin [20, 86], barley [87], sorghum [88], maize [89], beans [90], soybeans [91], cucumbers $[75,85,92]$, and cowpeas $[93,94]$.

The cation binding ability in the cowpea cell wall can be adjusted by Si [95]. Silicon is able to suppress Mn toxicity either by reducing the soluble apoplastic concentration of $\mathrm{Mn}$ in the cell wall or with apoplastic Mn detoxification [93, 94]. The results of a study by Iwasaki et al. show that released Si can cause Mn oxidation in the deposited form via relation with apoplast phenolic substances, which results in improving the tolerance of leaves to $\mathrm{Mn}[93,94]$. Silicon can decrease Mn toxicity by binding the majority of $\mathrm{Mn}$ in the cell walls of leaf tissues, and only a small amount of $\mathrm{Mn}$ is found in the symplast [96]. Silicon suppresses Mn toxicity in cucumbers by reducing the effects of membrane lipid peroxidation and increasing the enzymatic and nonenzymatic activities of antioxidants [85].

(2) Silicon and Cadmium Toxicity. Silicon can decrease cadmium (Cd) toxicity created by increasing the $\mathrm{pH}$ through a detoxification process. It has been reported that $\mathrm{Cd}$ uptake in plants is reduced through increasing obtainable $\mathrm{Si}$ and raising the $\mathrm{pH}$ [97]. The role of $\mathrm{Si}$ as a supplementation factor which is effective in decreasing $\mathrm{Cd}$ toxicity has been reported in cucumbers [98], maize [99-101], rice [102-104], Brassica chinensis [105], and peanuts [106]. Silicon minimises metal ion absorption and limits the transformation of toxic metals between the roots and shoots of rice seedlings grown in $\mathrm{Cd}$ [107]. Deposition of $\mathrm{Si}$ around the endodermis provides the potential to control $\mathrm{Cd}$ apoplastic transportation by physically obstructing the apoplast bypass flow in the root [107]. The Si treatment of maize under Cd stress significantly increased the biomass of the plant by reducing $\mathrm{Cd}$ availability and increasing soil $\mathrm{pH}$ [17]. The alleviating function of $\mathrm{Si}$ on $\mathrm{Cd}$ toxicity is not limited to the immobilising role through increased $\mathrm{pH}$ of soil, $\mathrm{Si}$ also aids in Cd detoxification in maize [17]. Silicon has a similar role in increasing the tolerance of plants to $\mathrm{Mn}$ and Cd toxicity by immobilising the metals in the cell walls of the root and inhibiting their transport to the 


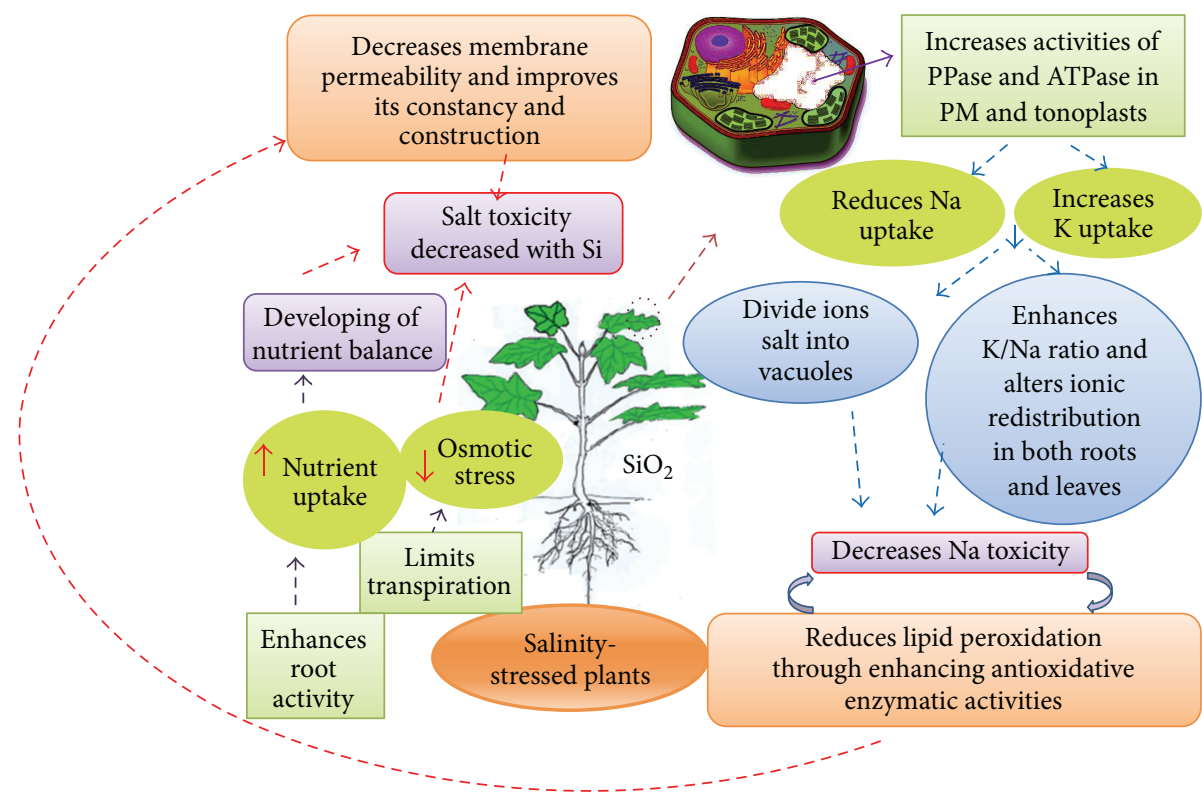

FIGURE 3: Schematic mechanism of the interaction of Si treatment and salt stressed plants.

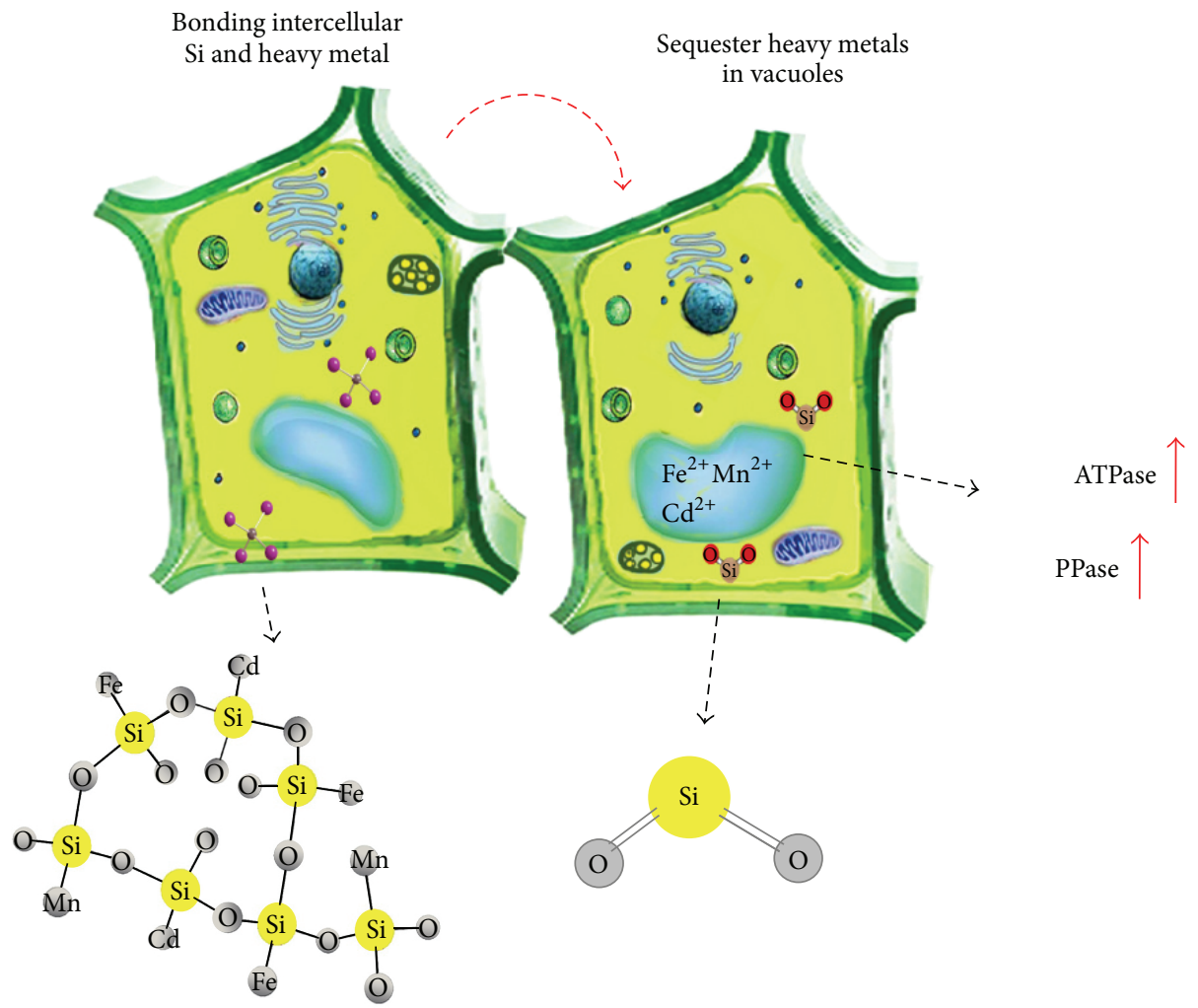

FIGURE 4: Interaction between intercellular Si and heavy metals.

cytosol $[93,94,96]$. These studies have suggested that $\mathrm{Si}$ is able to covalently bind with heavy metals and form an unstable silicate form (Figure 4), which subsequently suppresses the toxicity of the metals and is easily degraded to silicon dioxide $\left(\mathrm{SiO}_{2}\right)$. Hence, it can be figured out that $\mathrm{Si}$ displays crucial role in intercellular and extracellular parts of plants' cells. The extracellular activities of $\mathrm{Si}$ are by limiting penetration of heavy metals into the cytoplasm depending on its $\mathrm{Si}$ concentration. Sequestering of heavy metals in vacuoles is the intercellular activity of Si that happened in cytoplasm. 
(3) Silicon and Aluminium Toxicity. The suppressive effect on aluminium $(\mathrm{Al})$ toxicity in plants by $\mathrm{Si}$ treatment and the potential mechanisms of this suppression have been thoroughly investigated. The role of $\mathrm{Si}$ in the alleviation of $\mathrm{Al}$ toxicity is different between plant species. In this regard, $\mathrm{Si}$ can significantly decrease Al toxicity in Zea mays (Teosinte L. ssp. Mexicana), barley (Hordeum vulgare L.), soybeans (Glycine $\max$ L. Merr), and sorghum (Sorghum bicolor). However, in other species such as wheat (Triticum aestivum L.), rice (Oryza sativa L.), pea (Pisum sativum L.), and cotton (Gossypium hirsutum), Si is not effective in decreasing $\mathrm{Al}$ toxicity [108]. Additionally, using $\mathrm{Si}$ as an alternative detoxification method for $\mathrm{Al}$ toxicity has been reported in sorghum (Sorghum bicolor L.) [109, 110], tomato (Lycopersicum esculentum L.) [111], and barley (Hordeum vulgare L.) [112]. It has been documented that $\mathrm{Al}$ toxicity containment by $\mathrm{Si}$ in soybeans is not stable and depends on the $\mathrm{pH}$ [110]. The Al concentration can increase during Si treatment by forming hydroxyl-aluminosilicate complexes in the shoots of the plant. As a consequence of the increasing concentration the amount of $\mathrm{Al}$ transportation raised between the roots and shoots [113]. Moreover, $\mathrm{Si}$ is able to increase the Al tolerance of maize through phenolic compound metabolism, leading to more phenolics substances in the plant [114]. Catechin, quercetin, and other flavonoid-phenolics could potentially increase the heavy metal tolerance of plants.

\subsubsection{Silicon and Nutrient Imbalance}

(1) Silicon and Phosphorus. Silicon is able to increase crop yield under P-deficiency stress. Supplying Si in nutrient solutions of rice resulted in an increase of rice shoot dry weight [115]. Although Si does not influence P accessibility inside the soil, the fixation capacity of $\mathrm{P}$ is not affected by the concentration of silicic acid in the soil [116]. It has been shown that $\mathrm{P}$ uptake by plants cultured in both solution and soil is not affected by Si treatment $[115,116]$. Under P-deficiency, internal accessibility of $\mathrm{P}$ is controlled by other metals, such as $\mathrm{Mn}$ and Fe. Therefore, Si can increase $\mathrm{P}$ accessibility indirectly by decreasing the availability of Fe and Mn in plants [55].

Silicon can affect both deficiency and over dose stresses of P. Silicon is also able to suppress the damaging effects of excess $\mathrm{P}$ by decreasing extreme $\mathrm{P}$ absorption because Si deposition in root endodermal cells [117] may act as an apoplastic hindrance to decrease P uptake by roots.

(2) Silicon and Nitrogen. The Si accumulation in the leaf blades and stems of rice decreases the mutual shading and sensitivity of plants to diseases caused by high nitrogen availability. The occurrence of blast disease considerably decreased in the field after Si treatment, particularly when over dosage of $\mathrm{N}$ happened in soil with dense planting [118].

2.3.4. Silicon and Climate Condition. Silicon effectively decreases rice (Oryza sativa) damage under environmental stresses including inadequate sunshine, low temperature, and typhoons [20]. On the other hand, high Si accumulation in rice leads to increasing the culm wall thickness and vascular bundles size, consequently increasing the stem strength [119] and decreasing lodging. The deposition of Si on the hull stops the loss of water and allows the plant to withstand strong winds [120]. Moreover, the yield of Si treated rice productivity is unaffected by inadequate sunshine and low temperatures. There is less damage from electrolyte leakage as a result of high temperature on the leaves of Si treated plants than on the leaves of untreated plants [77].

\subsection{Silicon and Biotic Stresses}

2.4.1. Silicon and Plant Disease. Reportedly, $\mathrm{Si}$ is able to decrease the susceptibility of rice against sheath blight diseases [11, 121, 122]. Plant opal or glass and hard coating of $\mathrm{SiO}_{2}$ polymerisation in the plant cuticle layer is the possible mechanism for reducing disease susceptibility by $\mathrm{Si}$ [12]. The physical hindrance created by $\mathrm{SiO}_{2}$ enhances the incubation period in the leaf sheath of rice and results in impeding $R$. solani penetration to decrease the number and extension of sheath wounds. In comparison to the physical hindrance to early penetration, the lesion extension is a more important factor in terms of resistance to sheath blight disease, particularly in susceptible cultivars [123]. Silicon leads to increase the sheath blight resistance through creating a physical hindrance by $\mathrm{SiO}_{2}$ and reduce the intensity of disease. It has been speculated that $\mathrm{Si}$ is able to decrease the effect of sheath blight by motivating the defence mechanisms of the crops against pathogenesis, increase the amounts of phenolic components, and increase the activities of peroxidase, chitinases, polyphenoloxidase, $\beta$-1, 3-glucanases, and phenylalanine ammonialyase enzymes [12].

Several studies have reported the suppressive role of Si on rice blast disease caused by Magnaporthe grisea [121, 124, 125]. Silicon can reduce the intensity of blast disease in the leaf and the panicle during different growth stages. Reduction of the leaf lesions of rice after $96 \mathrm{hrs}$ of inoculation with $M$. grisea between Si-treated and untreated plants has been examined by Rodrigues et al. [124]. The experiment results indicated numerous coalescing and large lesions, regularly surrounded by a chlorotic halo, were observed on leaves of the untreated plant. However, separate and tiny lesions that seemed to be restricted at the expansion step were observed in Si-treated rice. Moreover, leaves of the control plants presented strong chlorosis compared to the Si-treated plants.

The intensity of neck and leaf blasts in both sensitive and partially resistant rice cultivars can be decreased via $\mathrm{Si}$ treatment depending on the rate of $\mathrm{Si}$ application and the disease severity [126]. Superior inherent disease severity at specific sites needs a lot of Si fertiliser to decrease the neck and leaf blast disease as effectively as in resistant rice cultivars. The Si has been applied to prevent the occurrence of powdery mildew disease, one of the plant diseases created by Sphaerotheca fuliginea. Silicon has been reported to be an effective suppressor of powdery mildew (Blumeria graminis) [8, 127-129]. Increasing the Si content in cucumber shoots leads to a decrease in powdery mildew incidence [130]. Additionally, it has been reported that the occurrence of powdery mildew disease decreased after increasing the concentration of $\mathrm{Si}$ in the culture solution [131]. The macroelement can 
decline infection efficiency, colony size, and conidia germination in cucumbers [132]. Effective use of $\mathrm{Si}$ in a foliar approach has been reported to help the growth of leaves in grapes, cucumbers (Cucumis sativus), and muskmelons (Cucumis melo) $[133,134]$. The growth trend most likely depends on the Si deposition on the surface of the leaves. Silicon also increases the tolerance of cucumber roots against $P$. aphanidermatum and Pythium ultimum fungal diseases [135]. Silicon also has prohibitive effect on rice green leafhoppers (Eurymela distinct), leaf spiders, brown plant hoppers [136], whitebacked planthoppers, and mites (Lorryia formosa) [137]. Along with all the above, the resistance of rice to the brown plant hopper (Nilaparvata lugens) is related to the Si content of plant [136]. Furthermore, it has been document that $\mathrm{Si}$ is able to increase the tolerance of sorghum (Sorghum bicolor) to anthracnose [138].

\section{Transportation and Deposition of Silicon}

The Si absorption intensity is variable depending on the plant species. Mitani and Ma carried out a study on transportation of Si by three different plant species including rice (Oryza sativa), tomato (Solanumly copersicum), and cucumbers (Cucumis sativus) with different $\mathrm{Si}$ absorption capacities (high, medium, and low) and indicated that Si transportation between the exterior solution and the cell cortical is controlled by a particular transporter $\left(K_{m}\right.$ value of $\left.15 \% \mathrm{mM}\right)$ in all three species [39]. However, these three species have different $v_{\max }$ from high to low, concluding that the transporter density differs between species. It has been speculated that Si transportation requires energy, and low temperature and metabolic repressors inhibit Si transportation [39]. Silicon transportation between cortical cells and the xylem is the most important factor which is responsible for high level of Si deposition in rice shoots. The lower Si deposition in some species, such as cucumbers (Cucumis sativus) and tomatoes (Solanumly copersicum), is related to lower Si transportation density between the exterior solution and the cortical cells or an imperfect Si transporter between the cortical cells and the xylem. Silicon absorption through xylem loading in rice is related to only one type of transporter. In comparison, transportation in cucumbers and tomatoes happens by different transporters. Following the $\mathrm{Si}$ absorption by the roots and translocation in the xylem, silica gel $\left(\mathrm{SiO}_{2} \cdot n \mathrm{H}_{2} \mathrm{O}\right)$ is formed by the polymerisation of the high concentration silicic acid $(>2 \mathrm{mM})$. The xylem sap in rice and wheat involves the extra Si concentration presented as monomeric silicic acid [43]. Water transpiration and $\mathrm{Si}$ polymerisation are the two main factors for producing a high concentration of silicic acid in plant shoots. By increasing the concentration of silicic acid, it is initially converted to colloidal silicic acid and after that to silica gel [54].

It has been reported that $\mathrm{Si}$ absorption and transportation in rice and maize with similar $\mathrm{Si}$-accumulator mechanism and in other species like wax gourd and sunflower as intermediate species are dependent on both plant species and outer $\mathrm{Si}$ concentration. All in all, the impact of plant species on $\mathrm{Si}$ uptake and Si transport is related to the ability of silicon absorption in passive or active form [139].
It has been demonstrated that silicification occurs in endodermis part of roots of gramineae during maturation. However, the cell walls of other tissues including vascular, epidermal, and cortical may be silicified in older roots. Also silicification occurs in various parts of grasses such as roots and shoot including leaves and culms, largely in the inflorescence [140].

Results of an investigation on rice [141] showed that a layer of deposited $\mathrm{Si}(2.5 \mu \mathrm{m})$ is formed instantly under the cuticle with a double layer of Si-cuticle in the leaf blades. The results also demonstrated that the silicification of cells including dumb-bell-shaped cells in vascular bundles, silica cells, and silica bodies on bulliform cells is not limited to the rice leaf blades because silicified cells can also be found within the epidermis layer and vascular tissue of leaf sheath, stem, and hull [141]. Results of other studies on Equisetum sp. revealed that the silicified structures were found on cell wall epidermal surface as discrete rosettes and knobs sheltered in spicules $[142,143]$. The location of this silica surface has effects on its thickness such as 3-7 mm in stem and 0.2-1.0 in leaf of plants.

Nuclear magnetic resonance (NMR) technique and colorimetric method have been used to investigate Si uptake in wheat [144]. The NMR technique was able to detect precisely any molecular species comprising Si. However, this technique only detected two silicic acid species (monomeric and dimeric) in earliest exudates and was not able to measure soluble $\mathrm{Si}$ in the later exudates using ${ }^{29} \mathrm{Si}-\mathrm{NMR}$ spectroscopy.

The silicified cells produced in leaf blades, vascular and epidermis stem tissues, and hull and leaf sheath play a protecting role against a variety of stresses in plants and provide functional archaeological and paleoecological information [52]. High Si deposition in rice decreases the ability of the roots to absorb $\mathrm{Si}$ [5]. Silicon absorption by the roots of rice is much higher than the roots of maize (Zea mays subsp. mays), wheat (Triticum spp.), rye (Secale cereale), barley (Hordeum vulgare L.), and sorghum [53].

The initial study of a Si transporter gene was in marine diatoms in 1997 [145]. The transportation of Si in naked Cylindrotheca fusiformis, a marine diatom, is encoded by a gene family [146]. Results of a study on transferring a diatom $\mathrm{Si}$ gene to a tobacco without an observed increase in $\mathrm{Si}$ absorption showed that the Si uptake mechanism is different between higher plants and diatoms [147]. It was speculated that the high Si content observed in rice shoots is not related to silicic acid diffusion through the lipid of the cell membrane [148]. However, there must be an active Si transporter in the roots of rice leading to high $\mathrm{Si}$ accumulation in the shoots $[148,149]$. The first active Si absorption gene (Lsil) between higher plants has been identified in rice [53, 147]. Three transporter genes Lsi1, Lsi2, and Lsi6 that are used to absorb and transport Si were identified in rice $[49,150]$. The Lsi1 was isolated from rice and was cloned, characterised, and functionally analysed in 2006 [151]. A Lsil mutant was used to find and map the genes responsible for Si xylem loading in rice [147].

Both Lsil and Lsi2 are located on the cell plasma membrane of endodermis and exodermis root cells on the distal side and proximal side, respectively $[150,151]$. The complementary DNA of Lsil is $1409 \mathrm{bp}$, and the deduced protein 


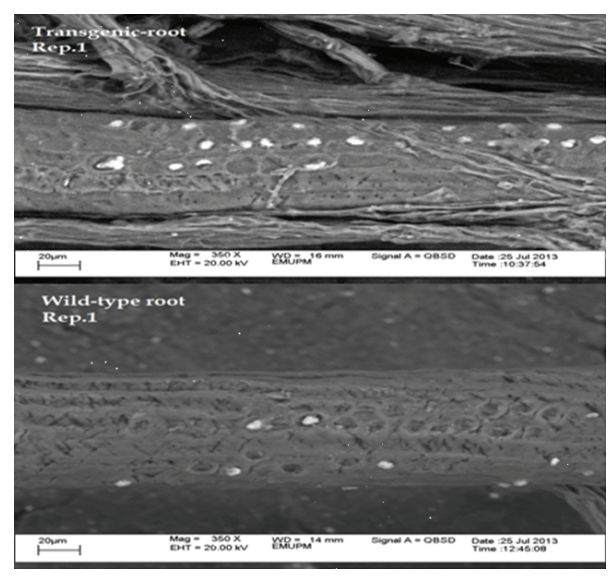

FIGURE 5: Electron microscopy image showing the Si accumulation (white spot) in transgenic and wild-type plant roots of Arabidopsis thaliana.

is 298 amino long. Expression of Lsi1 and Lsi2 has been observed constitutively in the roots of rice [151]. Lsi6 is similar to Lsi1 and Lsi2 and consists of five exons and four introns with an 894 bp open reading frame (ORF). Like Lsi1, Lsi6 encodes a protein of 298 amino acids. Lsi6 is expressed in the leaf blades, leaf sheaths, and roots, while Lsil and Lsi2 are only expressed in the roots. The predicted protein of both $L$ sil and Lsi6 consists of two well conserved NPA domains (Asn-ProAla) and four transmembrane domains $[34,49]$. In contrast to Lsi2, which acts as a silicic acid efflux transporter [150], both Lsi1 and Lsi6 genes are silicic acid influx transporters [49, $151,152]$. It has been reported that Lsil and Lsi2 significantly increase the absorption of Si by roots [150], while Lsi6 is involved in transferring of $\mathrm{Si}$ in shoots [49]. ZmLsil and $Z m L s i 6$ have been identified in Zea mays and are involved in $\mathrm{Si}$ absorption and transportation in different parts of the roots [153]. ZmLsil is expressed highly in the lateral roots and slightly in the crown roots. In contrast, $Z m L$ si6 is more highly expressed on the sheathes and blades of leaf and crown root [153].

It has been speculated that serine-rich proteins, prolinerich proteins, and other polysaccharides are involved in $\mathrm{Si}$ accumulation [154]. Recently, the serine-rich protein gene was isolated from the roots of mangroves (Rhizophora apiculata) that is possibly responsible for Si absorption and accumulation in plants [24]. Computational analysis of the cDNA cloned and isolated from mangrove roots treated with different concentrations of $\mathrm{Si}$ in different periods of time through the suppression subtractive hybridisation ( $\mathrm{SSH}$ ) indicated that the serine-rich protein gene has a $696 \mathrm{bp}$ coding region for a protein of 223 amino acids and is most likely involved in $\mathrm{Si}$ absorption and transportation in the roots of plants. The result of another survey [23] indicated that serine-rich protein gene increases amount of $\mathrm{Si}$ absorption and accumulation notably in the leaves and roots of transgenic Arabidopsis thaliana compared with wild-type plants (Figure 5). It can be suggested for future studies to provide some linkage between the polymerisation of amino acids-silicate and serinerich proteins.

\section{Biosilica Formation Mechanisms}

Plant species, diatoms, and sponges are able to accumulate, store, and process Si to create an elaborated pattern of biosilicas. The silica production by organisms is formed at atmospheric pressure and temperatures ranging from 4 to $40^{\circ} \mathrm{C}$ in an aqueous phase of saturated silica solution [155]. The mechanism of biosilica formation by organisms has been the subject of vast research and discussions till today. It was reported that an organic environment, containing a wide range of carbohydrates, proteins, lipids, phenolic compounds, and metal ions, may play a primary role in biosilica formation $[155,156]$.

The silica condensation in the nature is affected by many factors including silica concentration, $\mathrm{pH}$, temperature, and presence of other polymers, small molecules, and different ions. In all different silica species polymerization the angle of $\mathrm{Si}-\mathrm{O}-\mathrm{Si}$ bond and distances of $\mathrm{Si}-\mathrm{O}$ bond play the fundamental role. The material involved in silica polymerization containing $\mathrm{OH}$ groups and environmental reactions may differ in different species because of the solubility, composition, hardness, viscosity, and density [157].

Several in vitro and in vivo studies have been conducted to show the importance of biomolecules in biosilicification. Functional groups of all amino acids residues in protein's structure are accessible to silica and have a key role in determining the physical structure and nature of the substances which form during the maturing stages. It has been suggested that the role of amino acid in biosilicification may be the same as their in vivo role. In this case, effects of amino acids in biosilicification and their in vivo arrangements role can be a key factor to control biosilicification [158]. Peptides and amino acids are effective in creating polysilicic species via interactions with different species of silicate in the solution. Both forms of the silicate species, neutral $\mathrm{Si}(\mathrm{OH})_{4}$ and negatively charged $\left[\mathrm{SiO}(\mathrm{OH})_{3}\right]^{-}$, are implicated in the oxolation procedure (Figure 6).

The oxolation process results in $\mathrm{Si}$ polymerisation by concentrating silanol units and releasing $\mathrm{H}_{2} \mathrm{O}$ molecules. The SN2 nucleophilic substitution or oxolation process involves transferring internal proton through the transition state leading to produce $\mathrm{H}_{2} \mathrm{O}$ molecules in leaving form. The SN2 nucleophilic substitution can be base or acid catalyzed and $\mathrm{pH}$ is the main determinative factor for the rate of oxolation reaction. Oxolation process is highly dependent on the $\mathrm{pH}$. In case of silica it starts at $\mathrm{pH} \mathrm{3,} \mathrm{a} \mathrm{minimum} \mathrm{zero} \mathrm{charge,}$ and increased by increasing $\mathrm{pH}$. The $\mathrm{Si}$ polymerisation rate increases at $\mathrm{pH}$ as high as 8-9. Hydrogen bonds with silicate species and the electrostatic at traction between the groups of $\left(\mathrm{Si}-\mathrm{O}^{-}\right.$and $-\mathrm{NH}_{3}{ }^{+}$) are predicted to occur during oxolation (Figures 4 and 6 ). The $\mathrm{p} K_{a}$ of the amino acid side chains determines the ionisation in aqueous solution and creates the global charge.

The $\mathrm{p} K_{a}$ 's of the amino and carboxylic groups of amino acids are approximately 9 to 10 and 2, respectively. Hence, at a neutral $\mathrm{pH}$, the $(\mathrm{COOH})$ group of amino acids are $\left(\mathrm{COO}^{-}\right)$or negatively charged, whereas the amino group or $\left(\mathrm{NH}_{2} / \mathrm{NH}_{3}{ }^{+}\right)$of the amino acids must be protonated. In a study conducted to show the effects of four amino acids 


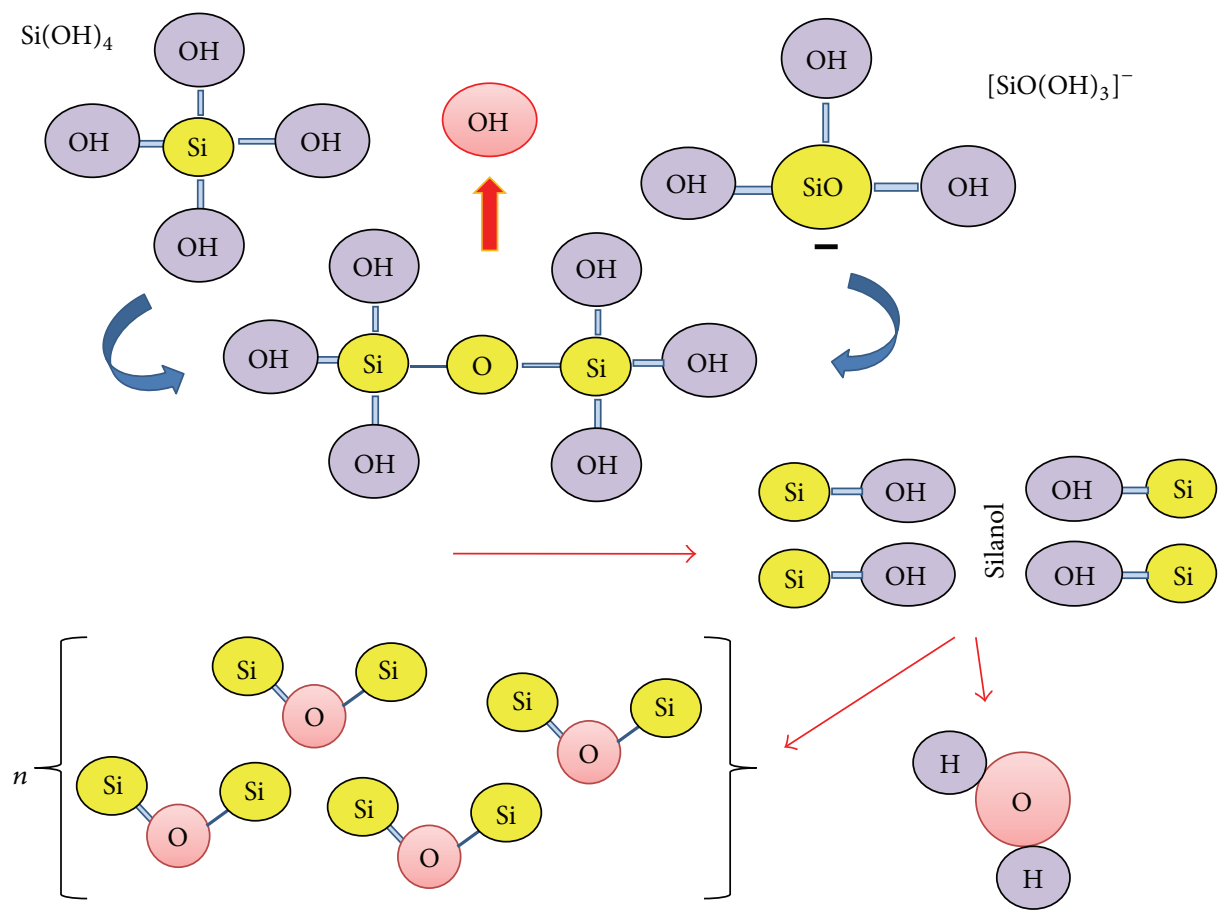

FIGURE 6: Schematic of Si species oxolation process.

(serine, proline, lysine, and aspartic acid) on polysilicate formation [159], the nucleophilic catalytic power of protonated amine groups was not observed. Furthermore, the number of $\mathrm{NH}_{3}{ }^{+}$groups decreased by increasing $\mathrm{pH}$, whereas it increased at the negative charge of the polysilicates. It was concluded that there must be some stability balance between these repercussions (Figure 7). The surface area of the silicate components may be affected by different amino acids depending on the hydrophobicity, the isoelectric point, and the silicate average pore size [158].

The results of another experiment showed that the carboxylic acid and alcohol groups of P-serine and P-asparagine amino acids did not have any significant role in the formation of the polysilicates, most likely due to the negative charge of these groups, on the other hand, the $-\mathrm{OH}$ side groups of serine appeared to be involved in hydrogen bond formation with $\mathrm{Si}(\mathrm{OH})_{4}$ [159]. However, it has been reported that the amine-terminated surfaces are not highlighted in silica nucleation; other substrates, such as carboxyl and hybrid $\left.\mathrm{NH}_{3}\left({ }^{+}\right) / \mathrm{COO}^{-}\right)$, are mainly active for silica accumulation. On the other hand, the free energy hindrances to forming the silica cluster are similar on both carboxyl- or amineterminated surface forms [160]. Among all of the amino acids, $\mathrm{p}$-Asp and $\mathrm{p}$-Ser are impressive catalysts at $\mathrm{pH} 4.9$, where the main silicate specie is neutral $\mathrm{Si}(\mathrm{OH})_{4}$. However, these amino acids are less energetic at $\mathrm{pH}$ 9.2, where the predominant silicate specie is negatively charged $\left[\mathrm{SiO}(\mathrm{OH})_{3}\right]^{-}[159]$. It has been shown that organic molecules containing hydroxylgroup are not involved chemically in the silica formation at all. Instead, they may only assist in rendering solubility and stability of the occluded organic molecules found in silica. In another view, it can be assumed that if hydroxyl-groups of organic molecules affect the silica formation, the polymerization of silicic acid would be encountered with water deficiency to increase the functional effects of protein's hydroxyl groups in the silica formation [161]. It can be predicted that the serine amino acid is appropriate for the oxolation process resulting in biosilica formation because this amino acid is neutral in terms of water solubility at different $\mathrm{pH}$ ranges and has a simple structure compared to other amino acids. As it is mentioned in the literature, the only form of Si that is absorbable by plants is monosilicic acid. Due to the dilution of the silicate solution, silanol molecules are not easily able to bond with amine groups. Therefore, the side groups of the amino acids and the carbonyl groups involved in the polypeptide chain are more likely to bring the molecules together, and biosilica formation occurs.

It can be understood that both amino acid and peptide can interact with silicate solutions via electrostatic interactions and hydrogen bonds. However, peptides seem to have a more significant effect than amino acids since hydrogen bonds or electrostatic interactions with a single molecule (amino acid) are not strong enough to a favorable condensation reaction. Since the condensation between molecular precursors occurs while species became close together it may be said that the distribution of hydrogen-bond (forming carbonyl groups) and charged side groups along the peptide chain brings species close to each other in the reactive. Moreover, the spontaneous collisions coming from Brownian motion are rather few in the silicate solutions [159]. 


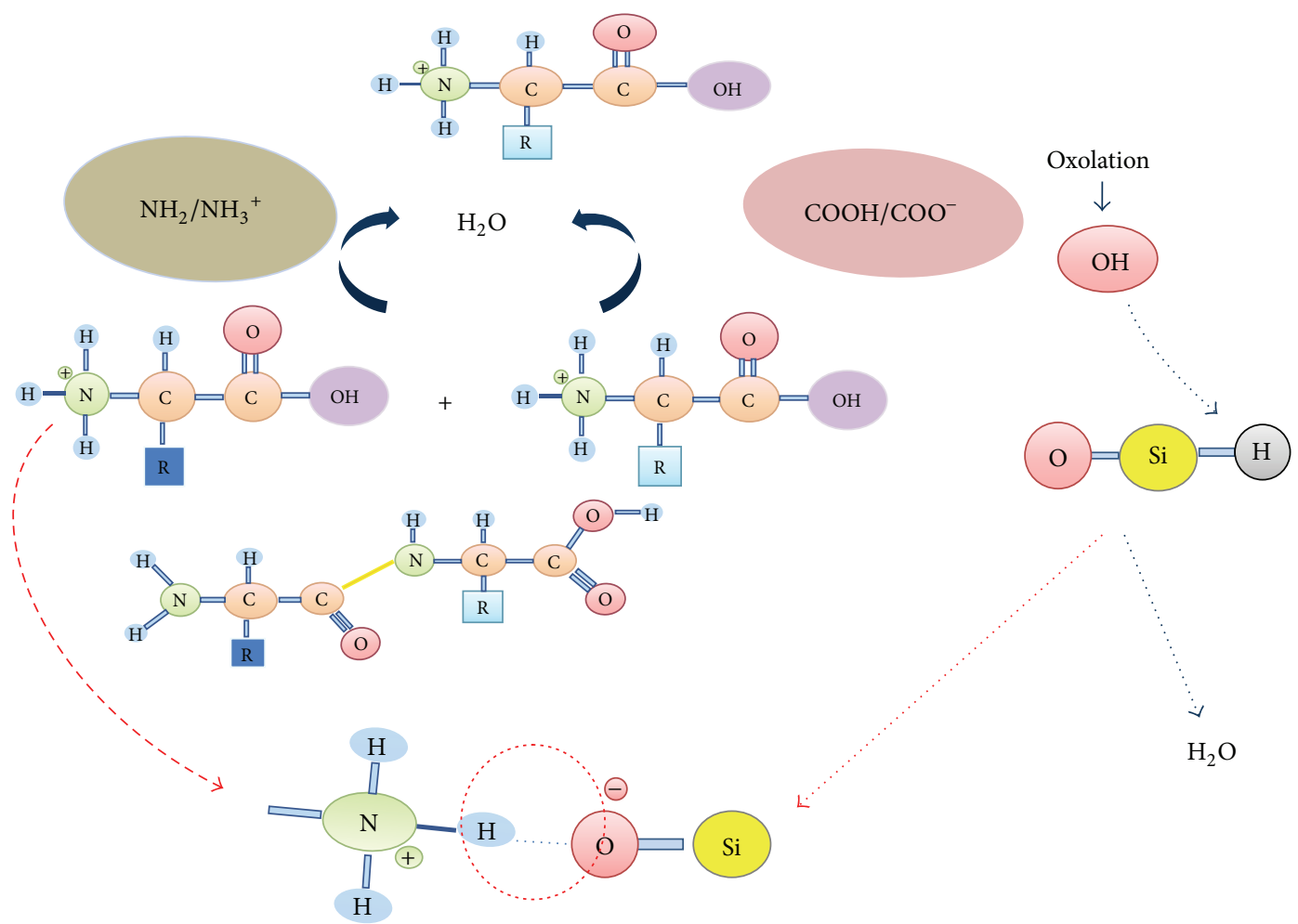

(a)

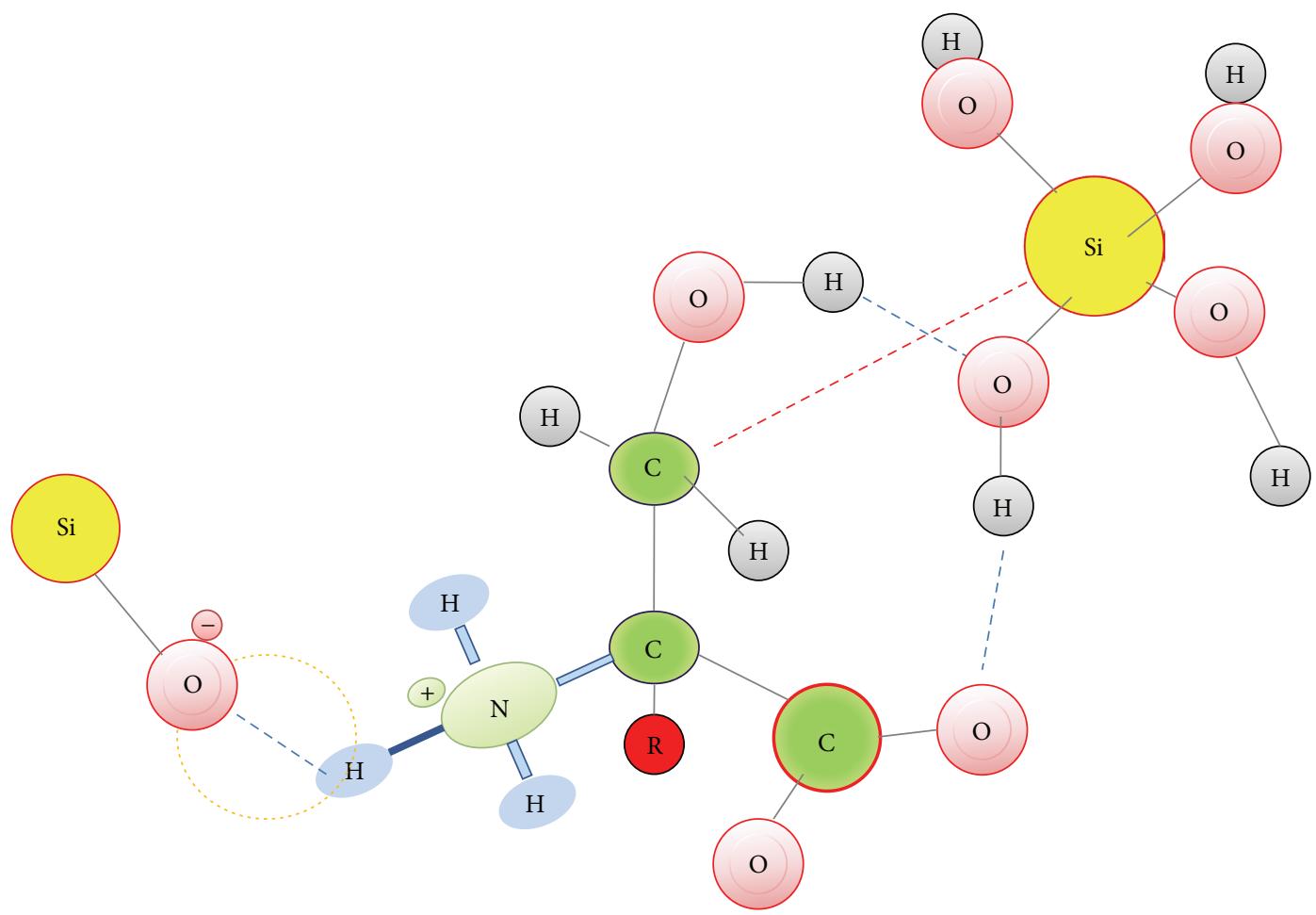

(b)

FIGURE 7: The putative relationship of the polymerisation of amino acids and silicate oxolation (a) and silicon (b). Blue dot row: hydrogen bond; red dot row: covalent bond. 


\section{Conclusions}

The primary purpose of this review is to provide comprehensive insight about the role of $\mathrm{Si}$ in plants and the effects of biomolecules that are involved in the biosilica formation mechanism. Silicon plays an important role in helping plants overcome different types of abiotic and biotic stresses. The macroelement also improves the soil conditions under toxic levels of heavy metals and several chemical elements. In addition to the role of $\mathrm{Si}$ as a physical hindrance, the application of Si could affect the physiological and metabolic activities of plants. It is reasonable to recommend $\mathrm{Si}$ as a useful element involved in cellular processes. Understanding the roles of $\mathrm{Si}$ on higher plants may improve their growth and productivity yield and decrease their susceptibility to a wide range of diseases. Because of 3 hydroxypropanoic groups, serine is classified as a hydrophilic, polar amino acid. Serine plays an important role in the anabolism of pyrimidines and purines. The structure of serine helps this amino acid to participate in other metabolites by easily releasing one atom of carbon in biosynthesis. Hence, serine is an important component in the biosilica formation mechanism and improvement of plant metabolism. Most of plants, especially dicots, are not able to absorb large quantities of Si from the soil. Hence, genetically and biochemically manipulating the plant roots to increase their capacity of $\mathrm{Si}$ absorption and subsequently transferring of $\mathrm{Si}$ to the shoot parts could help plants to overcome a wide range of stresses and improve their metabolism.

\section{Conflict of Interests}

The authors declare that there is no conflict of interests regarding the publication of this paper.

\section{References}

[1] E. Epstein, "Silicon in plants: facts vs. concepts," in Silicon in Agriculture, vol. 8, pp. 1-15, Elsevier, 2001.

[2] G. P. Bienert, M. D. Schüssler, and T. P. Jahn, "Metalloids: essential, beneficial or toxic? Major intrinsic proteins sort it out," Trends in Biochemical Sciences, vol. 33, no. 1, pp. 20-26, 2008.

[3] E. Epstein, "Silicon," Annual Review of Plant Physiology and Plant Molecular Biology, vol. 50, pp. 641-664, 1999.

[4] A. Fawe, M. Abou-Zaid, J. G. Menzies, and R. R. Bélanger, "Silicon-mediated accumulation of flavonoid phytoalexins in cucumber," Phytopathology, vol. 88, no. 5, pp. 396-401, 1998.

[5] K. E. Richmond and M. Sussman, "Got silicon? The non-essential beneficial plant nutrient," Current Opinion in Plant Biology, vol. 6, no. 3, pp. 268-272, 2003.

[6] A. Gunes, A. Inal, E. G. Bagci, and D. J. Pilbeam, "Silicon-mediated changes of some physiological and enzymatic parameters symptomatic for oxidative stress in spinach and tomato grown in sodic-B toxic soil," Plant and Soil, vol. 290, no. 1-2, pp. 103-114, 2007.

[7] H. Gong, X. Zhu, K. Chen, S. Wang, and C. Zhang, "Silicon alleviates oxidative damage of wheat plants in pots under drought," Plant Science, vol. 169, no. 2, pp. 313-321, 2005.

[8] W. Rémus-Borel, J. G. Menzies, and R. R. Bélanger, "Silicon induces antifungal compounds in powdery mildew-infected wheat," Physiological and Molecular Plant Pathology, vol. 66, no. 3, pp. 108-115, 2005.

[9] T. Hattori, S. Inanaga, H. Araki et al., "Application of silicon enhanced drought tolerance in Sorghum bicolor," Physiologia Plantarum, vol. 123, no. 4, pp. 459-466, 2005.

[10] Y. Nakata, M. Ueno, J. Kihara, M. Ichii, S. Taketa, and S. Arase, "Rice blast disease and susceptibility to pests in a silicon uptakedeficient mutant lsil of rice," Crop Protection, vol. 27, no. 3-5, pp. 865-868, 2008.

[11] G.-L. Zhang, Q.-G. Dai, and H.-C. Zhang, "Silicon application enhances resistance to sheath blight (Rhizoctonia solani) in rice," Journal of Plant Physiology and Molecular Biology, vol. 32, no. 5, pp. 600-606, 2006.

[12] F. Á. Rodrigues, F. X. R. Vale, G. H. Korndörfer et al., "Influence of silicon on sheath blight of rice in Brazil," Crop Protection, vol. 22, no. 1, pp. 23-29, 2003.

[13] O. L. Kvedaras, M. G. Keeping, R. Goebel, and M. Byrne, "Effects of silicon on the African stalk borer, Eldana saccharina (Lepidoptera: Pyralidae) in sugarcane," in Proceedings of the South African Sugar Technologists, pp. 359-362, 2005.

[14] Y. Liang, Q. Chen, Q. Liu, W. Zhang, and R. Ding, "Exogenous silicon $(\mathrm{Si})$ increases antioxidant enzyme activity and reduces lipid peroxidation in roots of salt-stressed barley (Hordeum vulgare L.)," Journal of Plant Physiology, vol. 160, no. 10, pp. 11571164, 2003.

[15] J. Wiese, H. Wiese, J. Schwartz, and S. Schubert, "Osmotic stress and silicon act additively in enhancing pathogen resistance in barley against barley powdery mildew," Journal of Plant Nutrition and Soil Science, vol. 168, no. 2, pp. 269-274, 2005.

[16] Z. Zhu, G. Wei, J. Li, Q. Qian, and J. Yu, "Silicon alleviates salt stress and increases antioxidant enzymes activity in leaves of salt-stressed cucumber (Cucumis sativus L.)," Plant Science, vol. 167, no. 3, pp. 527-533, 2004.

[17] Y. Liang, J. W. C. Wong, and L. Wei, "Silicon-mediated enhancement of cadmium tolerance in maize (Zea mays L.) grown in cadmium contaminated soil," Chemosphere, vol. 58, no. 4, pp. 475-483, 2005.

[18] Y. Wang, A. Stass, and W. J. Horst, "Apoplastic binding of aluminum is involved in silicon-induced amelioration of aluminum toxicity in maize," Plant physiology, vol. 136, no. 3, pp. 3762-3770, 2004.

[19] X. Gao, C. Zou, L. Wang, and F. Zhang, "Silicon improves water use efficiency in maize plants," Journal of Plant Nutrition, vol. 27, no. 8, pp. 1457-1470, 2005.

[20] J. F. Ma, Y. Miyake, and E. Takahashi, "Silicon as a beneficial element for crop plants," in Silicon in Agriculture, vol. 8, pp. 1739, Elsevier, 2001.

[21] E. Takahashi, J. F. Ma, and Y. Miyake, "The possibility of silicon as an essential element for higher plants," Comments on Agricultural and Food Chemistry, vol. 2, no. 2, pp. 99-102, 1990.

[22] E. Epstein, "The anomaly of silicon in plant biology," Proceedings of the National Academy of Sciences of the United States of America, vol. 91, no. 1, pp. 11-17, 1994.

[23] M. Sahebi, M. M. Hanafi, A. S. N. Akmar, M. Y. Rafii, P. Azizi, and A. S. Idris, "Serine-rich protein is a novel positive regulator for silicon accumulation in mangrove," Gene, vol. 556, no. 2, pp. 170-181, 2015.

[24] M. Sahebi, M. M. Hanafi, S. N. A. Abdullah et al., "Isolation and expression analysis of novel silicon absorption gene from roots of mangrove (Rhizophora apiculata) via suppression subtractive hybridization," BioMed Research International, vol. 2014, Article ID 971985, 11 pages, 2014. 
[25] D. S. Orlov, Humus Acids of Soils, Oxonian Press, 1985.

[26] V. V. Matychenkov and G. S. Snyder, "Mobile silicon-bound compounds in some soils of Southern Florida," Eurasian Soil Science, vol. 12, pp. 1165-1173, 1996.

[27] V. V. Matichenkov, Y. M. Ammosova, and E. A. Bocharnikova, "The method for determination of plant available silica in soil," Agrochemistry, vol. 1, pp. 76-84, 1997.

[28] R. A. Khalid and J. A. Silva, "Residual effect of calcium silicate on $\mathrm{Ph}$, phosphorus, and aluminum in a tropical soil profile," Soil Science and Plant Nutrition, vol. 26, no. 1, pp. 87-98, 1980.

[29] V. V. Matychenkov and Y. M. Ammosova, "Effect of amorphous silica on some properties of a sod-podzolic soil," Eurasian Soil Science, vol. 28, no. 10, pp. 87-99, 1996.

[30] D. G. Lumsdon and V. C. Farmer, "Solubility characteristics of proto-imogolite sols: how silicic acid can de-toxify aluminium solutions," European Journal of Soil Science, vol. 46, no. 2, pp. 179-186, 1995.

[31] C. Exley and J. D. Birchall, "A mechanism of hydroxyaluminosilicate formation," Polyhedron, vol. 12, no. 9, pp. 1007-1017, 1993.

[32] V. V. Matychenkov, D. L. Pinskiy, and Y. A. Bocharnikova, "Influence of mechanical compaction of soils on the state and form of available silicon," Eurasian Soil Science, vol. 27, no. 12, pp. 58-67, 1995.

[33] G. H. Snyder, V. V. Matichenkov, and L. E. Datnoff, "Silicon," in Plant Nutrition, pp. 551-562, Taylor \& Francis, Belle Glade, Fla, USA, 2006.

[34] F. M. Jian, K. Tamai, N. Yamaji et al., "A silicon transporter in rice," Nature, vol. 440, no. 7084, pp. 688-691, 2006.

[35] W. H. Casey, S. D. Kinrade, C. T. G. Knight, D. W. Rains, and E. Epstein, "Aqueous silicate complexes in wheat, Triticum aestivum L," Plant, Cell \& Environment, vol. 27, no. 1, pp. 51-54, 2004.

[36] D. A. Barber and M. G. T. Shone, "The absorption of silica from aqueous solutions by plants," Journal of Experimental Botany, vol. 17, no. 3, pp. 569-578, 1966.

[37] S. C. Jarvis, “The uptake and transport of silicon by perennial ryegrass and wheat," Plant and Soil, vol. 97, no. 3, pp. 429-437, 1987.

[38] H. F. Bakhat, S. Hanstein, and S. Schubert, "Optimal level of silicon for maize (Zea mays L. cv AMADEO) growth in nutrient solution under controlled conditions," in Proceedings of the 16th International Plant Nutrition Colloquium, Davis, Calif, USA, 2009.

[39] N. Mitani and J. F. Ma, "Uptake system of silicon in different plant species," Journal of Experimental Botany, vol. 56, no. 414, pp. 1255-1261, 2005.

[40] Y. Liang, J. Si, and V. Römheld, "Silicon uptake and transport is an active process in Cucumis sativus," New Phytologist, vol. 167, no. 3, pp. 797-804, 2005.

[41] M. Nikolic, N. Nikolic, Y. Liang, E. A. Kirkby, and V. Römheld, "Germanium-68 as an adequate tracer for silicon transport in plants. Characterization of silicon uptake in different crop species," Plant Physiology, vol. 143, no. 1, pp. 495-503, 2007.

[42] Y. Liang, H. Hua, Y.-G. Zhu, J. Zhang, C. Cheng, and V. Römheld, "Importance of plant species and external silicon concentration to active silicon uptake and transport," New Phytologist, vol. 172, no. 1, pp. 63-72, 2006.

[43] N. Mitani, F. M. Jian, and T. Iwashita, "Identification of the silicon form in xylem sap of rice (Oryza sativa L.)," Plant and Cell Physiology, vol. 46, no. 2, pp. 279-283, 2005.
[44] V. Matichenkov and E. Bocharnikova, "Si in horticultural industry," in Production Practices and Quality Assessment of Food Crops, vol. 2, pp. 217-228, Springer, Dordrecht, The Netherlands, 2004.

[45] L. Waterken, A. Bienfait, and A. Peeters, "Callose et silice epidermiques. Rapports avec la transpiration cuticulaire," Cellule, vol. 73, no. 3, 1981.

[46] F. Á. Rodrigues, N. Benhamou, L. E. Datnoff, J. B. Jones, and R. R. Bélanger, "Ultrastructural and cytochemical aspects of silicon-mediated rice blast resistance," Phytopathology, vol. 93, no. 5, pp. 535-546, 2003.

[47] R. R. Bélanger, N. Benhamou, and J. G. Menzies, "Cytological evidence of an active role of silicon in wheat resistance to powdery mildew (Blumeria graminis f. sp. tritici)," Phytopathology, vol. 93, no. 4, pp. 402-412, 2003.

[48] P. B. Kaufman, P. Dayanandan, Y. Takeoka, W. C. Bigelow, J. D. Jones, and R. Iler, "Silica in shoots of higher plants," in Silicon and Siliceous Structures in Biological Systems, pp. 409449, Springer, New York, NY, USA, 1981.

[49] N. Yamaji, N. Mitatni, and F. M. Jian, "A transporter regulating silicon distribution in rice shoots," The Plant Cell, vol. 20, no. 5, pp. 1381-1389, 2008.

[50] S. Yoshida, "Chemical aspects of the role of silicon in physiology of the rice plant," Bulletin of the National Institute of Agricultural Sciences Series B, vol. 15, pp. 1-58, 1965.

[51] A. Woesz, J. C. Weaver, M. Kazanci et al., "Micromechanical properties of biological silica in skeletons of deep-sea sponges," Journal of Materials Research, vol. 21, no. 8, pp. 2068-2078, 2006.

[52] M. J. Hodson, P. J. White, A. Mead, and M. R. Broadley, "Phylogenetic variation in the silicon composition of plants," Annals of Botany, vol. 96, no. 6, pp. 1027-1046, 2005.

[53] K. Tamai and J. F. Ma, "Characterization of silicon uptake by rice roots," New Phytologist, vol. 158, no. 3, pp. 431-436, 2003.

[54] J. Ma and E. Takahashi, Soil, Fertilizer, and Plant Silicon Research in Japan, Elsevier, Amsterdam, The Netherlands, 2002.

[55] J. F. Ma, "Role of silicon in enhancing the resistance of plants to biotic and abiotic stresses," Soil Science and Plant Nutrition, vol. 50, no. 1, pp. 11-18, 2004.

[56] M. A. Tahir, T. Aziz, M. Ashraf, S. Kanwal, and M. A. Maqsood, "Beneficial effects of silicon in wheat (Triticum aestivum L.) under salinity stress," Pakistan Journal of Botany, vol. 38, no. 5, pp. 1715-1722, 2006.

[57] K. Al-aghabary, Z. Zhu, and Q. Shi, "Influence of silicon supply on chlorophyll content, chlorophyll fluorescence, and antioxidative enzyme activities in tomato plants under salt stress," Journal of Plant Nutrition, vol. 27, no. 12, pp. 2101-2115, 2004.

[58] R. Ahmad, S. H. Zaheer, and S. Ismail, "Role of silicon in salt tolerance of wheat (Triticum aestivum L.)," Plant Science, vol. 85, no. 1, pp. 43-50, 1992.

[59] H. J. Gong, D. P. Randall, and T. J. Flowers, "Silicon deposition in the root reduces sodium uptake in rice (Oryza sativa L.) seedlings by reducing bypass flow," Plant, Cell \& Environment, vol. 29, no. 10, pp. 1970-1979, 2006.

[60] Y. Liang, W. Zhang, Q. Chen, Y. Liu, and R. Ding, "Effect of exogenous silicon $(\mathrm{Si})$ on $\mathrm{H}^{+}$-ATPase activity, phospholipids and fluidity of plasma membrane in leaves of salt-stressed barley (Hordeum vulgare L.)," Environmental and Experimental Botany, vol. 57, no. 3, pp. 212-219, 2006.

[61] M. Bradbury and R. Ahmad, "The effect of silicon on the growth of Prosopis juliflora growing in saline soil," Plant and Soil, vol. 125 , no. 1, pp. 71-74, 1990. 
[62] M. R. Romero-Aranda, O. Jurado, and J. Cuartero, "Silicon alleviates the deleterious salt effect on tomato plant growth by improving plant water status," Journal of Plant Physiology, vol. 163, no. 8, pp. 847-855, 2006.

[63] E. Yildirim, M. Turan, and I. Guvenc, "Effect of foliar salicylic acid applications on growth, chlorophyll, and mineral content of cucumber grown under salt stress," Journal of Plant Nutrition, vol. 31, no. 3, pp. 593-612, 2008.

[64] H. R. Moussa, "Influence of exogenous application of silicon on physiological response of salt-stressed maize (Zea mays L.)," International Journal of Agriculture and Biology, vol. 8, no. 2, pp. 293-297, 2006.

[65] C. Kaya, L. Tuna, and D. Higgs, "Effect of silicon on plant growth and mineral nutrition of maize grown under waterstress conditions," Journal of Plant Nutrition, vol. 29, no. 8, pp. 1469-1480, 2006.

[66] T. Matoh, P. Kairusmee, and E. Takahashi, "Salt-induced damage to rice plants and alleviation effect of silicate," Soil Science and Plant Nutrition, vol. 32, no. 2, pp. 295-304, 1986.

[67] Y. Liang, Q. Shen, Z. Shen, and T. Ma, "Effects of silicon on salinity tolerance of two barley cultivars," Journal of Plant Nutrition, vol. 19, no. 1, pp. 173-183, 1996.

[68] Y. Liang, "Effects of silicon on enzyme activity and sodium, potassium and calcium concentration in barley under salt stress," Plant and Soil, vol. 209, no. 2, pp. 217-224, 1999.

[69] A. R. Yeo, S. A. Flowers, G. Rao, K. Welfare, N. Senanayake, and T. J. Flowers, "Silicon reduces sodium uptake in rice (Oryza sativa L.) in saline conditions and this is accounted for by a reduction in the transpirational bypass flow," Plant, Cell and Environment, vol. 22, no. 5, pp. 559-565, 1999.

[70] G. Soylemezoglu, K. Demir, A. Inal, and A. Gunes, "Effect of silicon on antioxidant and stomatal response of two grapevine (Vitis vinifera L.) rootstocks grown in boron toxic, saline and boron toxic-saline soil," Scientia Horticulturae, vol. 123, no. 2, pp. 240-246, 2009.

[71] A. Shalata and M. Tal, "The effect of salt stress on lipid peroxidation and antioxidants in the leaf of the cultivated tomato and its wild salt-tolerant relative Lycopersicon pennellii," Physiologia Plantarum, vol. 104, no. 2, pp. 169-174, 1998.

[72] S. Meneguzzo, F. Navari-Izzo, and R. Izzo, "Antioxidative responses of shoots and roots of wheat to increasing $\mathrm{NaCI}$ concentrations," Journal of Plant Physiology, vol. 155, no. 2, pp. 274-280, 1999.

[73] D. R. Gossett, E. P. Millhollon, and M. C. Lucas, "Antioxidant response to $\mathrm{NaCl}$ stress in salt-tolerant and salt-sensitive cultivars of cotton," Crop Science, vol. 34, no. 3, pp. 706-714, 1994.

[74] A. Hashemi, A. Abdolzadeh, and H. R. Sadeghipour, "Beneficial effects of silicon nutrition in alleviating salinity stress in hydroponically grown canola, Brassica napus L., plants," Soil Science and Plant Nutrition, vol. 56, no. 2, pp. 244-253, 2010.

[75] J. D. Maksimović, J. Bogdanović, V. Maksimović, and M. Nikolic, "Silicon modulates the metabolism and utilization of phenolic compounds in cucumber (Cucumis sativus L.) grown at excess manganese," Journal of Plant Nutrition and Soil Science, vol. 170, no. 6, pp. 739-744, 2007.

[76] T. Hattori, S. Inanaga, E. Tanimoto, A. Lux, M. Luxová, and Y. Sugimoto, "Silicon-induced changes in viscoelastic properties of Sorghum root cell walls," Plant and Cell Physiology, vol. 44, no. 7, pp. 743-749, 2003.

[77] S. Agarie, N. Hanaoka, O. Ueno et al., "Effects of silicon on tolerance to water deficit and heat stress in rice plants (Oryza sativa L.), monitored by electrolyte leakage," Plant Production Science, vol. 1, no. 2, pp. 96-103, 1998.

[78] M. Ashraf, M. Afzal, R. Ahmed, F. Mujeeb, A. Sarwar, and L. Ali, "Alleviation of detrimental effects of $\mathrm{NaCl}$ by silicon nutrition in salt-sensitive and salt-tolerant genotypes of sugarcane (Saccharum officinarum L.)," Plant and Soil, vol. 326, no. 1-2, pp. 381-391, 2010.

[79] M. Saqib, C. Zörb, and S. Schubert, "Silicon-mediated improvement in the salt resistance of wheat (Triticum aestivum) results from increased sodium exclusion and resistance to oxidative stress," Functional Plant Biology, vol. 35, no. 7, pp. 633-639, 2008.

[80] A. L. Tuna, C. Kaya, D. Higgs, B. Murillo-Amador, S. Aydemir, and A. R. Girgin, "Silicon improves salinity tolerance in wheat plants," Environmental and Experimental Botany, vol. 62, no. 1, pp. 10-16, 2008.

[81] D. Savvas, D. Giotis, E. Chatzieustratiou, M. Bakea, and G. Patakioutas, "Silicon supply in soilless cultivations of zucchini alleviates stress induced by salinity and powdery mildew infections," Environmental and Experimental Botany, vol. 65, no. 1, pp. 11-17, 2009.

[82] R. Romero-Aranda, T. Soria, and J. Cuartero, "Tomato plantwater uptake and plant-water relationships under saline growth conditions," Plant Science, vol. 160, no. 2, pp. 265-272, 2001.

[83] D. E. Williams and J. Vlamis, "The effect of silicon on yield and manganese-54 uptake and distribution in the leaves of barley plants grown in culture solutions," Plant Physiology, vol. 32, no. 5, pp. 404-409, 1957.

[84] D. E. Williams and J. Vlamis, "Manganese toxicity in standard culture solutions," Plant and Soil, vol. 8, no. 3, pp. 183-193, 1957.

[85] Q. Shi, Z. Bao, Z. Zhu, Y. He, Q. Qian, and J. Yu, "Siliconmediated alleviation of Mn toxicity in Cucumis sativus in relation to activities of superoxide dismutase and ascorbate peroxidase," Phytochemistry, vol. 66, no. 13, pp. 1551-1559, 2005.

[86] K. Iwasaki and A. Matsumura, "Effect of silicon on alleviation of manganese toxicity in pumpkin (Cucurbita moschata Duch cv. Shintosa)," Soil Science and Plant Nutrition, vol. 45, no. 4, pp. 909-920, 1999.

[87] T. Horiguchi and S. Morita, "Mechanism of manganese toxicity and tolerance of plants VI. Effect of silicon on alleviation of manganese toxicity of barley," Journal of Plant Nutrition, vol. 10, no. 17, pp. 2299-2310, 1987.

[88] L. Galvez, R. B. Clark, L. M. Gourley, and J. W. Maranville, "Effects of silicon on mineral composition of sorghum grown with excess manganese," Journal of Plant Nutrition, vol. 12, no. 5, pp. 547-561, 1989.

[89] S. Doncheva, C. Poschenrieder, Z. Stoyanova, K. Georgieva, M. Velichkova, and J. Barceló, "Silicon amelioration of manganese toxicity in Mn-sensitive and Mn-tolerant maize varieties," Environmental and Experimental Botany, vol. 65, no. 2-3, pp. 189-197, 2009.

[90] W. J. Horst and H. Marschner, "Effect of silicon on manganese tolerance of bean plants (Phaseolus vulgaris L.)," Plant and Soil, vol. 50, no. 1-3, pp. 287-303, 1978.

[91] J. Kluthcouski and L. E. Nelson, "The effect of silicon on the manganese nutrition of soybeans (Glycine max (L.) Merrill)," Plant and Soil, vol. 56, no. 1, pp. 157-160, 1980.

[92] Q. Shi and Z. Zhu, "Effects of exogenous salicylic acid on manganese toxicity, element contents and antioxidative system in cucumber," Environmental and Experimental Botany, vol. 63, no. 1-3, pp. 317-326, 2008. 
[93] K. Iwasaki, P. Maier, M. Fecht, and W. J. Horst, "Leaf apoplastic silicon enhances manganese tolerance of cowpea (Vigna unguiculata)," Journal of Plant Physiology, vol. 159, no. 2, pp. 167-173, 2002.

[94] K. Iwasaki, P. Maier, M. Fecht, and W. J. Horst, "Effects of silicon supply on apoplastic manganese concentrations in leaves and their relation to manganese tolerance in cowpea (Vigna unguiculata (L.) Walp.)," Plant and Soil, vol. 238, no. 2, pp. 281$288,2002$.

[95] W. J. Horst, M. Fecht, A. Naumann, A. H. Wissemeier, and P. Maier, "Physiology of manganese toxicity and tolerance in Vigna unguiculata (L.) Walp," Journal of Plant Nutrition and Soil Science, vol. 162, no. 3, pp. 273-274, 1999.

[96] H. Rogalla and V. Römheld, "Role of leaf apoplast in siliconmediated manganese tolerance of Cucumis sativus L," Plant, Cell \& Environment, vol. 25, no. 4, pp. 549-555, 2002.

[97] H. M. Chen, C. R. Zheng, C. Tu, and Z. G. Shen, "Chemical methods and phytoremediation of soil contaminated with heavy metals," Chemosphere, vol. 41, no. 1-2, pp. 229-234, 2000.

[98] J. Feng, Q. Shi, X. Wang, M. Wei, F. Yang, and H. Xu, "Silicon supplementation ameliorated the inhibition of photosynthesis and nitrate metabolism by cadmium (Cd) toxicity in Cucumis sativus L," Scientia Horticulturae, vol. 123, no. 4, pp. 521-530, 2010.

[99] M. Vaculík, A. Lux, M. Luxová, E. Tanimoto, and I. Lichtscheidl, "Silicon mitigates cadmium inhibitory effects in young maize plants," Environmental and Experimental Botany, vol. 67, no. 1, pp. 52-58, 2009.

[100] K. P. V. da Cunha and C. W. A. do Nascimento, "Silicon effects on metal tolerance and structural changes in Maize (Zea mays L.) grown on a cadmium and zinc enriched soil," Water, Air, and Soil Pollution, vol. 197, no. 1-4, pp. 323-330, 2009.

[101] K. P. V. da Cunha, C. W. A. do Nascimento, and A. J. da Silva, "Silicon alleviates the toxicity of cadmium and zinc for maize (Zea mays L.) grown on a contaminated soil," Journal of Plant Nutrition and Soil Science, vol. 171, no. 6, pp. 849-853, 2008.

[102] C. Zhang, L. Wang, Q. Nie, W. Zhang, and F. Zhang, "Longterm effects of exogenous silicon on cadmium translocation and toxicity in rice (Oryza sativa L.)," Environmental and Experimental Botany, vol. 62, no. 3, pp. 300-307, 2008.

[103] C. C. Nwugo and A. J. Huerta, "Effects of silicon nutrition on cadmium uptake, growth and photosynthesis of rice plants exposed to low-level cadmium," Plant and Soil, vol. 311, no. 12, pp. 73-86, 2008.

[104] X.-H. Shi, H. Wang, and F. S. Zhang, "Research on the mechanism of silica improving the resistance of rice seedlings to Cd," Journal of Agro-Environment Science, vol. 25, no. 5, pp. 1112-1116, 2006.

[105] A. Song, Z. Li, J. Zhang, G. Xue, F. Fan, and Y. Liang, "Silicon-enhanced resistance to cadmium toxicity in Brassica chinensis $\mathrm{L}$. is attributed to Si-suppressed cadmium uptake and transport and Si-enhanced antioxidant defense capacity," Journal of Hazardous Materials, vol. 172, no. 1, pp. 74-83, 2009.

[106] G. Shi, Q. Cai, C. Liu, and L. Wu, "Silicon alleviates cadmium toxicity in peanut plants in relation to cadmium distribution and stimulation of antioxidative enzymes," Plant Growth Regulation, vol. 61, no. 1, pp. 45-52, 2010.

[107] X. Shi, C. Zhang, H. Wang, and F. Zhang, "Effect of Si on the distribution of Cd in rice seedlings," Plant and Soil, vol. 272, no. 1-2, pp. 53-60, 2005.
[108] M. J. Hodson and D. E. Evans, "Aluminium/silicon interactions in higher plants," Journal of Experimental Botany, vol. 46, no. 2, pp. 161-171, 1995.

[109] L. Galvez and R. B. Clark, "Effects of silicon on growth and mineral composition of sorghum (Sorghum Bicolor) grown with toxic levels of aluminium," in Plant-Soil Interactions at Low $\mathrm{pH}$, vol. 45 of Developments in Plant and Soil Sciences, pp. 805-823, Springer, Dordrecht, The Netherlands, 1991.

[110] A. D. Baylis, C. Gragopoulou, K. J. Davidson, and J. D. Birchall, "Effects of silicon on the toxicity of aluminium to soybean," Communications in Soil Science \& Plant Analysis, vol. 25, no. 5-6, pp. 537-546, 1994.

[111] D. E. Peaslee and C. R. Frink, "Influence of silicie acid on uptake of $\mathrm{Mn}, \mathrm{Al}, \mathrm{Zn}$, and $\mathrm{Cu}$ by tomatoes (Lycopersicum esculentum) grown on an acid soil," Soil Science Society of America Journal, vol. 33, no. 4, pp. 569-571, 1969.

[112] L. Yongchao and D. Ruixing, "Influence of silicon on microdistribution of mineral ions in roots of salt-stressed barley as associated with salt tolerance in plants," Science in China, Series C: Life Sciences, vol. 45, no. 3, pp. 298-308, 2002.

[113] J. D. Birchall, "Role of silicon in biology," Chemistry in Britain, vol. 26, no. 2, pp. 141-144, 1990.

[114] P. S. Kidd, M. Llugany, C. Poschenrieder, B. Gunsé, and J. Barceló, "The role of root exudates in aluminium resistance and silicon-induced amelioration of aluminium toxicity in three varieties of maize (Zea mays L.)," Journal of Experimental Botany, vol. 52, no. 359, pp. 1339-1352, 2001.

[115] J. Ma and E. Takahashi, "Effect of silicon on the growth and phosphorus uptake of rice," Plant and Soil, vol. 126, no. 1, pp. 115-119, 1990.

[116] J. Ma and E. Takahashi, "The effect of silicic acid on rice in a P-deficient soil," Plant and Soil, vol. 126, no. 1, pp. 121-125, 1990.

[117] A. Lux, M. Luxová, J. Abe, E. Tanimoto, T. Hattori, and S. Inanaga, "The dynamics of silicon deposition in the sorghum root endodermis," New Phytologist, vol. 158, no. 3, pp. 437-441, 2003.

[118] N. Ohyama, "Amelioration of cold weather damage of rice by silicate fertilizer application," Agriculture Horticulture, vol. 60, pp. 1385-1389, 1985.

[119] S. Shimoyama, "Effect of silicon on lodging and wind damage in rice," Report for the Research Funds Granted by Ministry of Agriculture 82, 1958.

[120] J. F. Ma, K. Tamai, M. Ichii, and G. F. Wu, "A rice mutant defective in Si uptake," Plant Physiology, vol. 130, no. 4, pp. 21112117, 2002.

[121] K. Cai, D. Gao, S. Luo, R. Zeng, J. Yang, and X. Zhu, "Physiological and cytological mechanisms of silicon-induced resistance in rice against blast disease," Physiologia Plantarum, vol. 134, no. 2, pp. 324-333, 2008.

[122] F. A. Rodrigues and L. E. Datnoff, "Silicon and rice disease management," Fitopatologia Brasileira, vol. 30, no. 5, pp. 457469, 2005.

[123] F. Á. R. Peters, L. E. Datnoff, G. H. Korndörfer, K. W. Seebold, and M. C. Rush, "Effect of silicon and host resistance on sheath blight development in rice," Plant Disease, vol. 85, no. 8, pp. 827832, 2001.

[124] F. Á. Rodrigues, D. J. McNally, L. E. Datnoff et al., "Silicon enhances the accumulation of diterpenoid phytoalexins in rice: a potential mechanism for blast resistance," Phytopathology, vol. 94, no. 2, pp. 177-183, 2004. 
[125] K. W. Seebold Jr., L. E. Datnoff, F. J. Correa-Victoria, T. A. Kucharek, and G. H. Snyder, "Effects of silicon and fungicides on the control of leaf and neck blast in upland rice," Plant Disease, vol. 88, no. 3, pp. 253-258, 2004.

[126] K. W. Seebold, L. E. Datnoff, F. J. Correa-Victoria, T. A. Kucharek, and G. H. Snyder, "Effect of silicon rate and host resistance on blast, scald, and yield of upland price," Plant Disease, vol. 84, no. 8, pp. 871-876, 2000.

[127] Y. C. Liang, W. C. Sun, J. Si, and V. Römheld, "Effects of foliarand root-applied silicon on the enhancement of induced resistance to powdery mildew in Cucumis sativus," Plant Pathology, vol. 54, no. 5, pp. 678-685, 2005.

[128] M.-H. Guével, J. G. Menzies, and R. R. Bélanger, "Effect of root and foliar applications of soluble silicon on powdery mildew control and growth of wheat plants," European Journal of Plant Pathology, vol. 119, no. 4, pp. 429-436, 2007.

[129] F. Fauteux, F. Chain, F. Belzile, J. G. Menzies, and R. R. Bélanger, "The protective role of silicon in the Arabidopsis-powdery mildew pathosystem," Proceedings of the National Academy of Sciences of the United States of America, vol. 103, no. 46, pp. 17554-17559, 2006.

[130] Y. Miyake and E. Takahashi, "Effect of silicon on the growth of solution-cultured cucumber plant," Soil Science and Plant Nutrition, vol. 29, no. 1, pp. 71-83, 1983.

[131] T. Kanto, "Research of silicate for improvement of plant defense against pathogens in Japan," in Second Silicon in Agriculture Conference, Kyoto, Japan, T. Matohe, Ed., pp. 22-26, Press-Net, 2002.

[132] J. G. Menzies, D. L. Ehret, A. D. M. Glass, and A. L. Samuels, "The influence of silicon on cytological interactions between Sphaerotheca fuliginea and Cucumis sativus," Physiological and Molecular Plant Pathology, vol. 39, no. 6, pp. 403-414, 1991.

[133] P. Bowen, J. Menzies, D. Ehret, L. Samuels, and A. D. M. Glass, "Soluble silicon sprays inhibit powdery mildew development on grape leaves," Journal of the American Society for Horticultural Science, vol. 117, no. 6, pp. 906-912, 1992.

[134] J. Menzies, P. Bowen, D. Ehret, and A. D. M. Glass, "Foliar applications of potassium silicate reduce severity of powdery mildew on cucumber, muskmelon, and zucchini squash," Journal of the American Society for Horticultural Science, vol. 117, no. 6, pp. 902-905, 1992.

[135] M. Cherif, A. Asselin, and R. R. Belanger, "Defense responses induced by soluble silicon in cucumber roots infected by Pythium spp," Phytopathology, vol. 84, no. 3, pp. 236-242, 1994.

[136] G. Sujatha, G. P. Reddy, and M. M. K. Murthy, Effect of Certain Biochemical Factors on Expression of Resistance of Rice Varieties to Brown Plant Hopper (Nilaparvata lugens Stal.), Andhra Pradesh Agricultural University, 1987.

[137] N. K. Savant, G. H. Snyder, and L. E. Datnoff, "Silicon management and sustainable rice production," Advances in Agronomy, vol. 58, pp. 151-199, 1996.

[138] R. S. Resende, F. Á. Rodrigues, R. V. Costa, and D. D. Silva, "Silicon and fungicide effects on anthracnose in moderately resistant and susceptible Sorghum Lines," Journal of Phytopathology, vol. 161, no. 1, pp. 11-17, 2013.

[139] Y. Liang, W. Sun, Y.-G. Zhu, and P. Christie, "Mechanisms of silicon-mediated alleviation of abiotic stresses in higher plants: a review," Environmental Pollution, vol. 147, no. 2, pp. 422-428, 2007.

[140] A. G. Sangster, M. J. Hodson, and H. J. Tubb, "Chapter 5 silicon deposition in higher plants," Studies in Plant Science, vol. 8, pp. 85-113, 2001.
[141] C. J. Prychid, P. J. Rudall, and M. Gregory, "Systematics and biology of silica bodies in monocotyledons," The Botanical Review, vol. 69, no. 4, pp. 377-440, 2003.

[142] G. Holzhüter, K. Narayanan, and T. Gerber, "Structure of silica in Equisetum arvense," Analytical and Bioanalytical Chemistry, vol. 376, no. 4, pp. 512-517, 2003.

[143] C. C. Perry and M. A. Fraser, "Silica deposition and ultrastructure in the cell wall of Equisetum arvense: the importance of cell wall structures and flow control in biosilicification?" Philosophical Transactions of the Royal Society B: Biological Sciences, vol. 334, no. 1269, pp. 149-157, 1991.

[144] W. H. Casey, S. D. Kinrade, C. T. G. Knight, D. W. Rains, and E. Epstein, "Aqueous silicate complexes in wheat, Triticum aestivum L," Plant, Cell and Environment, vol. 27, no. 1, pp. 51-54, 2004.

[145] C. L. de la Rocha, M. A. Brzezinski, and M. J. DeNiro, "Fractionation of silicon isotopes by marine diatoms during biogenic silica formation," Geochimica et Cosmochimica Acta, vol. 61, no. 23, pp. 5051-5056, 1997.

[146] P. Curnow, L. Senior, M. J. Knight, K. Thamatrakoln, M. Hildebrand, and P. J. Booth, "Expression, purification, and reconstitution of a diatom silicon transporter," Biochemistry, vol. 51, no. 18, pp. 3776-3785, 2012.

[147] J. F. Ma, N. Mitani, S. Nagao et al., "Characterization of the silicon uptake system and molecular mapping of the silicon transporter gene in rice," Plant physiology, vol. 136, no. 2, pp. 3284-3289, 2004.

[148] J. A. Raven, "Silicon transport at the cell and tissue level," in Silicon in Agriculture, vol. 8, pp. 41-55, Elsevier, 2001.

[149] J. F. Ma, S. Goto, K. Tamai, and M. Ichii, "Role of root hairs and lateral roots in silicon uptake by rice," Plant Physiology, vol. 127, no. 4, pp. 1773-1780, 2001.

[150] J. F. Ma, N. Yamaji, N. Mitani et al., "An efflux transporter of silicon in rice," Nature, vol. 448, no. 7150, pp. 209-212, 2007.

[151] J. F. Ma and N. Yamaji, "Silicon uptake and accumulation in higher plants," Trends in Plant Science, vol. 11, no. 8, pp. 392397, 2006.

[152] N. Mitani, N. Yamaji, and J. F. Ma, "Characterization of substrate specificity of a rice silicon transporter, Lsil," Pflugers Archiv European Journal of Physiology, vol. 456, no. 4, pp. 679-686, 2008.

[153] N. Mitani, N. Yamaji, and J. F. Ma, "Identification of maize silicon influx transporters," Plant and Cell Physiology, vol. 50, no. 1, pp. 5-12, 2009.

[154] H. Kauss, K. Seehaus, R. Franke, S. Gilbert, R. A. Dietrich, and N. Kröger, "Silica deposition by a strongly cationic proline-rich protein from systemically resistant cucumber plants," The Plant Journal, vol. 33, no. 1, pp. 87-95, 2003.

[155] H. A. Currie and C. C. Perry, "Silica in plants: biological, biochemical and chemical studies," Annals of Botany, vol. 100, no. 7, pp. 1383-1389, 2007.

[156] C. C. Harrison, "Evidence for intramineral macromolecules containing protein from plant silicas," Phytochemistry, vol. 41, no. 1, pp. 37-42, 1996.

[157] C. C. Perry, "Silicification: the processes by which organisms capture and mineralize silica," Reviews in Mineralogy and Geochemistry, vol. 54, no. 1, pp. 291-327, 2003.

[158] D. Belton, G. Paine, S. V. Patwardhan, and C. C. Perry, "Towards an understanding of (bio)silicification: the role of amino acids and lysine oligomers in silicification," Journal of Materials Chemistry, vol. 14, no. 14, pp. 2231-2241, 2004. 
[159] T. Coradin and J. Livage, "Effect of some amino acids and peptides on silicic acid polymerization," Colloids and Surfaces B: Biointerfaces, vol. 21, no. 4, pp. 329-336, 2001.

[160] A. F. Wallace, J. J. DeYoreo, and P. M. Dove, "Kinetics of silica nucleation on carboxyl- and amine-terminated surfaces: insights for biomineralization," Journal of the American Chemical Society, vol. 131, no. 14, pp. 5244-5250, 2009.

[161] G. E. Tilburey, S. V. Patwardhan, J. Huang, D. L. Kaplan, and C. C. Perry, "Are hydroxyl-containing biomolecules important in biosilicification? A model study," The Journal of Physical Chemistry B, vol. 111, no. 17, pp. 4630-4638, 2007. 

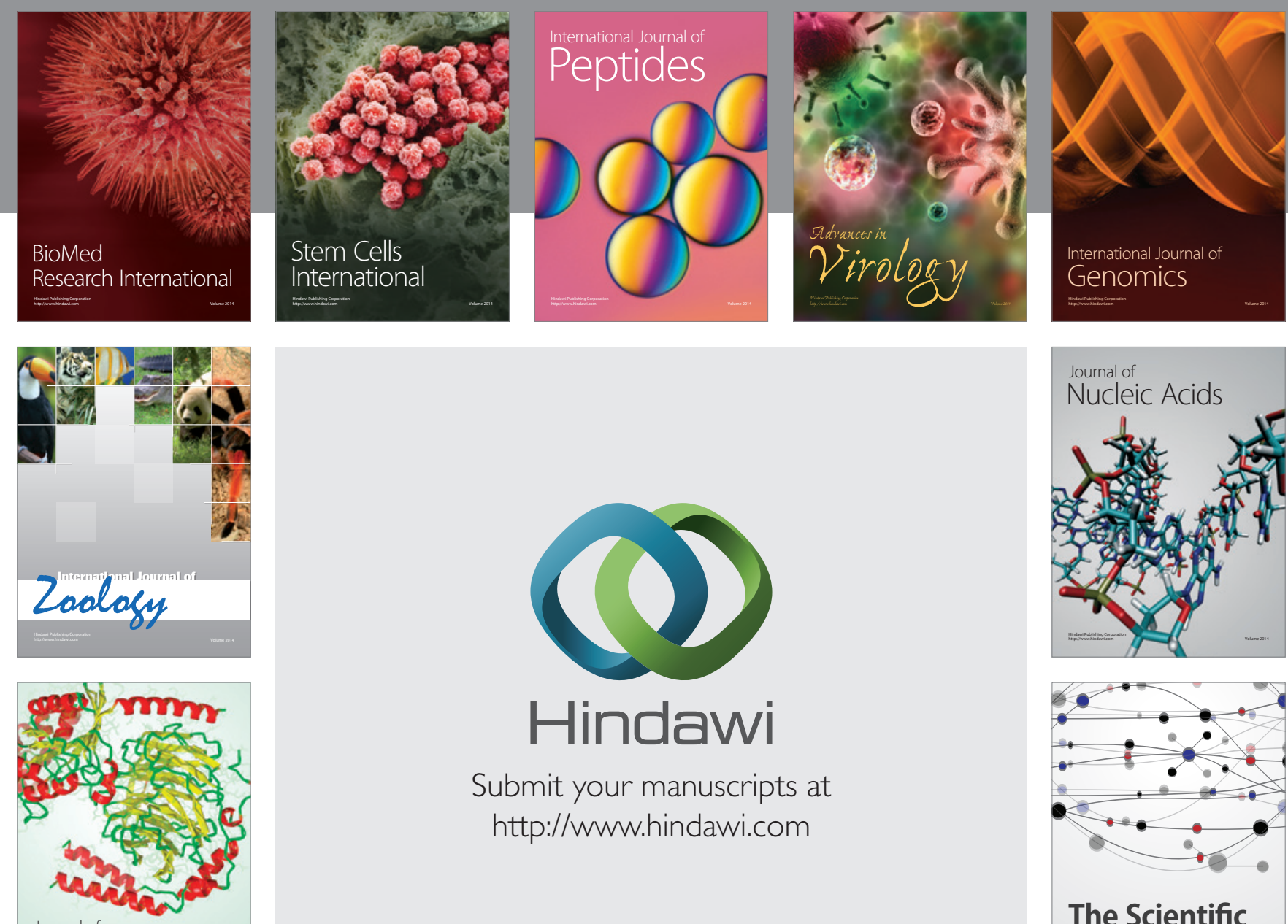

Submit your manuscripts at

http://www.hindawi.com

Journal of
Signal Transduction
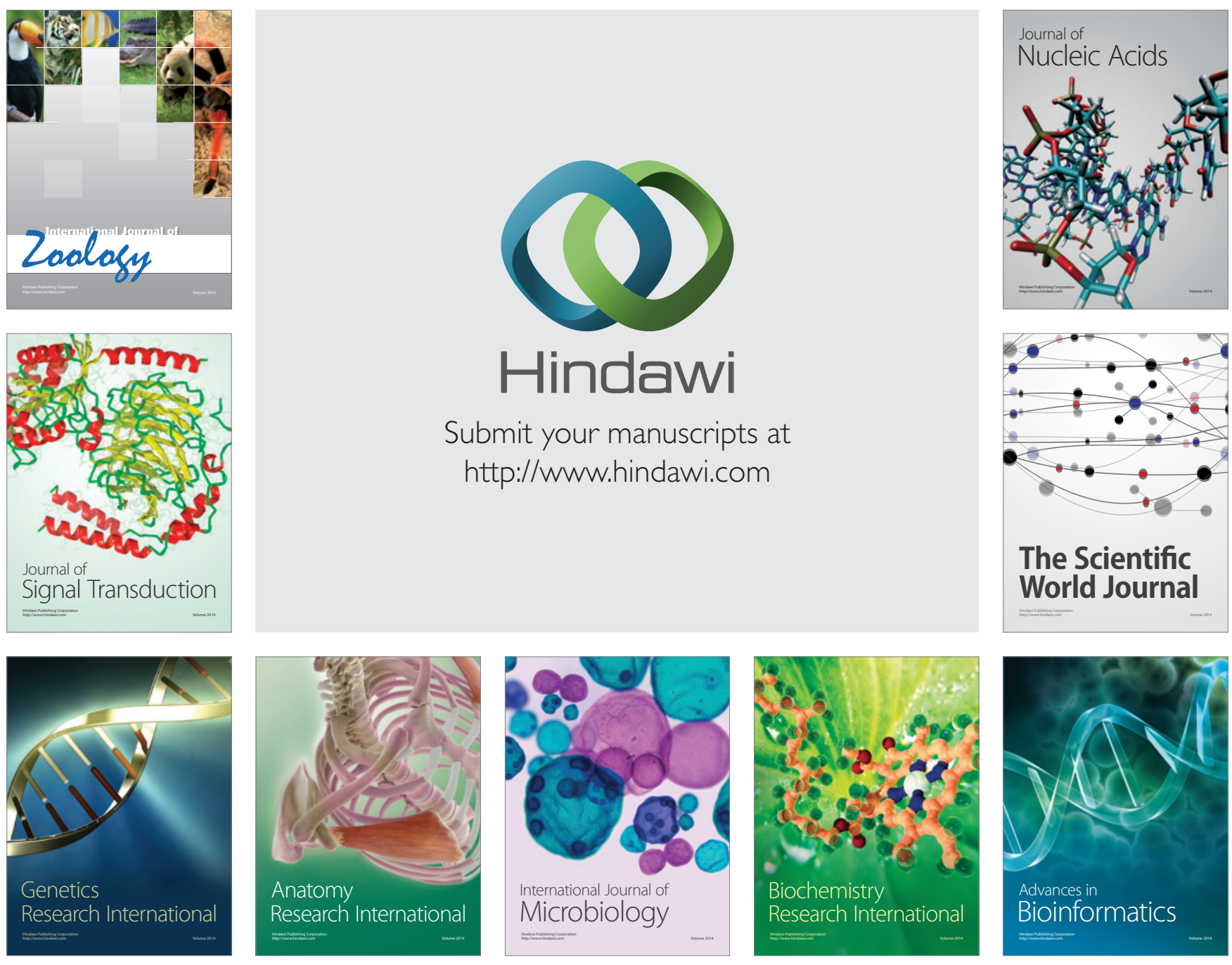

The Scientific World Journal
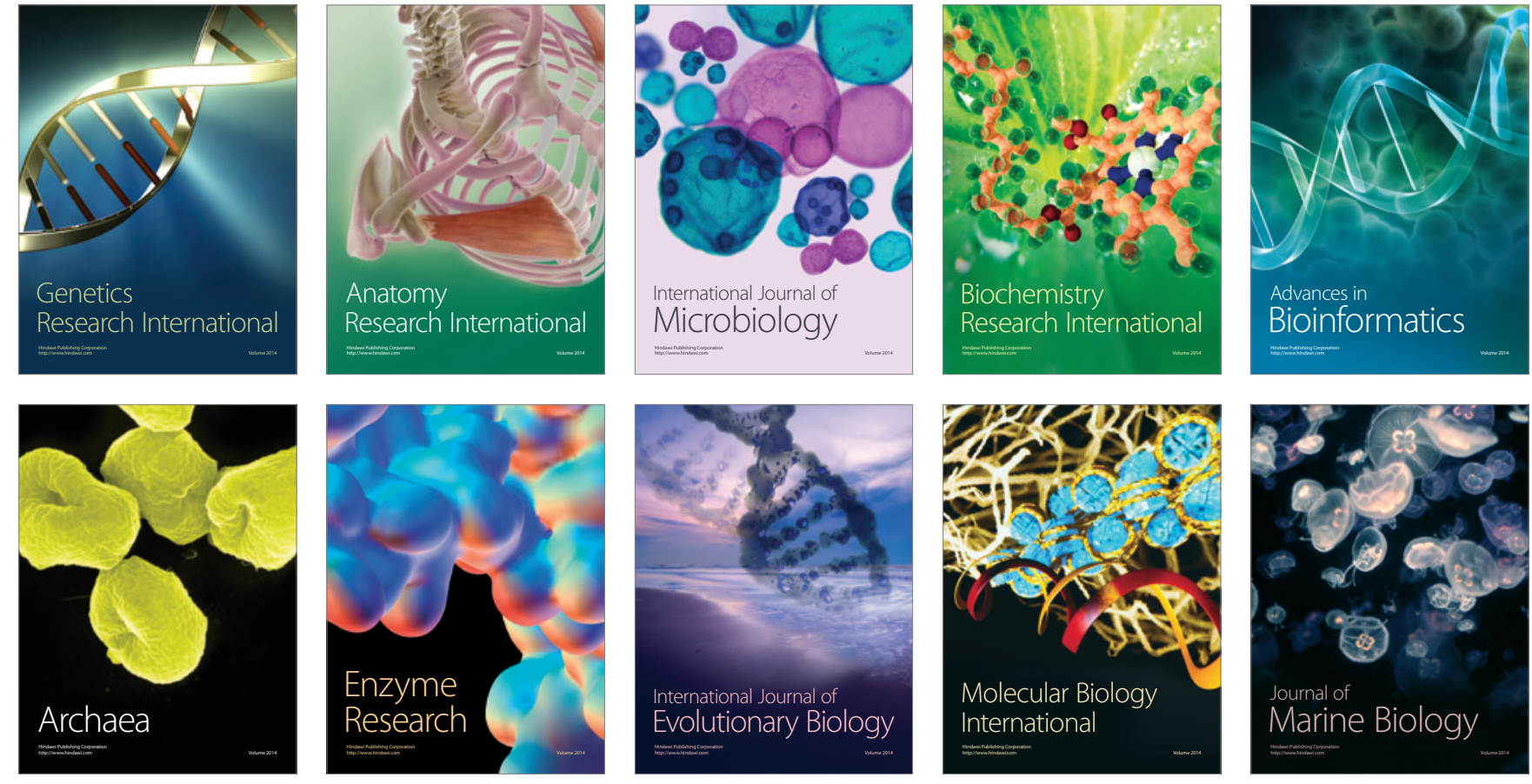